\title{
Cleft Palate
}

\author{
P. V. Narayanan and H. S. Adenwalla
}

\subsection{Introduction}

It was Kilner who said, "Ask not for a spatula and torch to check your cleft palate repair, but listen to your patient speak." By this obvious but profound statement, he drew the cleft surgeons' attention to the fact that gone are the days of breakdowns and fistulae and that if your child does not speak well, your operation is a failure, for such a child would be out of the mainstream of life forever. In spite of the advances in technique and execution, experienced cleft surgeons all over the world still struggle to obtain perfect speech in a large percentage of cases.

In view of the obvious difficulties of intraoral surgery, it is not surprising that cleft lips were repaired way before anyone tried to repair a cleft palate. Credit for the first successful repair of a cleft palate goes to Le Monnier, a French dentist from Roven. Le Monnier in 1766 cauterized to freshen the cleft edges and sutured them successfully [1].

Cleft surgery then passed through a stormy period of uncertainty in the hands of giants like Ferdinand von Graefe [2], Roux, Dupuytren [3], Dieffenbach [4], and Warren [5]. Mucosal flaps were used, and even lateral osteotomies were tried to move the hard palate medially. In 1859, almost a hundred years after the first hard palate was repaired, von Langenbeck [6] emphasized the need to raise mucoperiosteal bipedicled flaps to repair a palate. Langenbeck procedure was a fundamental breakthrough, and with this major advance, breakdowns of the palate were reduced. In its wake

Electronic Supplementary Material The online version of this chapter (https://doi.org/10.1007/978-981-15-1346-6_73) contains supplementary material, which is available to authorized users.

P. V. Narayanan $(\triangle)$

Consultant Plastic Surgeon, Jubilee Mission Medical College and Research Institute, Thrissur, Kerala, India

H. S. Adenwalla

Department of Plastic Surgery, Burns and the Charles Pinto Centre for Cleft Lip, Palate and Craniofacial Anomalies, Jubilee Mission

Medical College and Research Institute, Thrissur, Kerala, India refinements followed. In 1931, Victor Veau [7] parted from the bipedicled flap to single pedicled flaps based on the greater palatine vessels. Veau stressed the importance of repairing the nasal lining of the palate and the need to lengthen it.

In 1937, Kilner [8] working in Oxford and Wardill [9] working in Newcastle on Tyne independently used a four flap procedure for the complete cleft palate.

The weakness of this procedure was a high fistula rate at the junction of the four flaps. In the 1940s, Dorrance [10], Cronin [11], and others used various flaps to lengthen the palate. In 1966 Millard [12] introduced his island flaps based on the greater palatine arteries to lengthen the nasal lining. Ravin Thatte [13] went a step further and took two island flaps one for lining and one for cover and used a tongue flap on the denuded hard palate. All these procedures had their day but were short lived in popularity. However, special mention must be made of the buccal myomucosal flap originally called the cheek flap by Padgett [14]. This flap was revived 30 years later by Murari Mukherjee [15] of Calcutta. He changed the direction of the flap. Recently Ian Jackson has introduced muscle into this mucosal flap to make it more robust, and he calls it a myomucosal flap. He uses it in all his palates to lengthen the nasal lining by $1.5 \mathrm{~cm}$ and believes that as a result he achieves better speech. Robert Mann [16] does a Furlow's and coves the residual raw areas with two buccal flaps. His rationale is that there is deficiency of tissue in the palate and therefore, on first plastic surgical principles, bring in tissue from outside. This may become the philosophy of the future.

\subsection{Embryology and Anatomy (Figs. 72.1 and 77.1)}

\subsubsection{Embryology}

The primary palate is derived from the intermaxillary segment derived from the frontonasal and medial nasal 
prominences. The main part of the definitive palate is formed by two shelf-like outgrowths from the maxillary prominences. These outgrowths, the palatine shelves, appear in the sixth week of development and are directed obliquely downward on each side of the tongue (Fig. 73.1a and b).

In the seventh week, however, the palatine shelves ascend to attain a horizontal position above the tongue and fuse, forming the secondary palate (Fig. 73.2a and b). Anteriorly, the shelves fuse with the triangular primary palate, and the incisive foramen is the midline landmark between the pri- mary and secondary palates. At the same time as the palatine shelves fuse, the nasal septum grows down and joins with the cephalic aspect of the newly formed palate (Fig. 73.3a and b).

The secondary palate lies posterior to the incisive foramen and consists of the bony hard palate anteriorly and the soft palate posteriorly, terminating at the uvula. The hard palate consists of the palatine bony shelves on either side, attached to the vomer in the midline. The soft palate consists of a sandwich of muscles enveloped by oral and nasal mucosa.

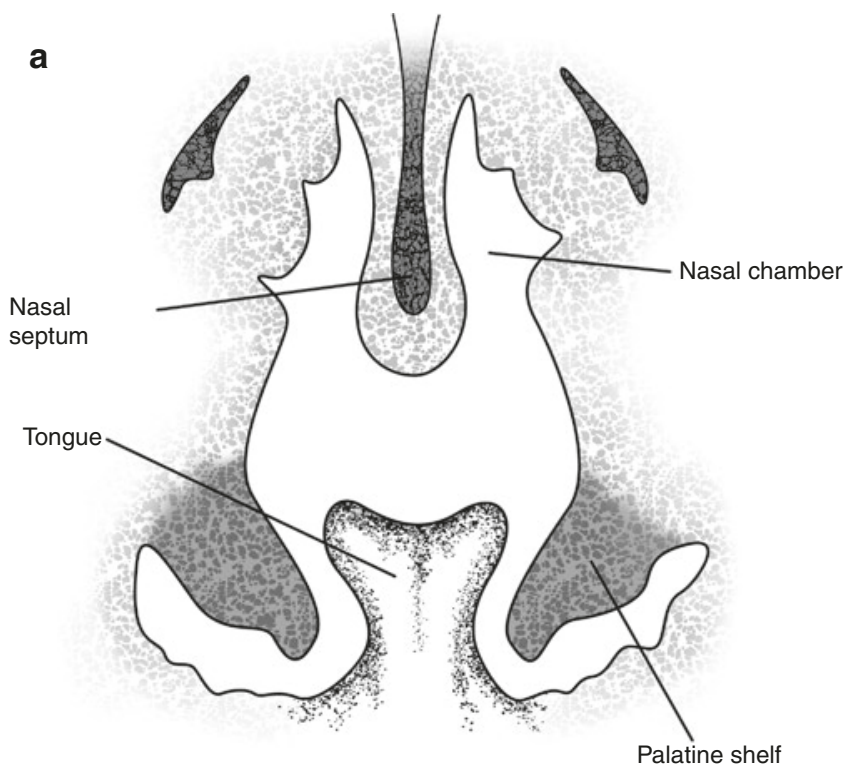

CAssociation of Oral and Maxillofacial Surgeons of India

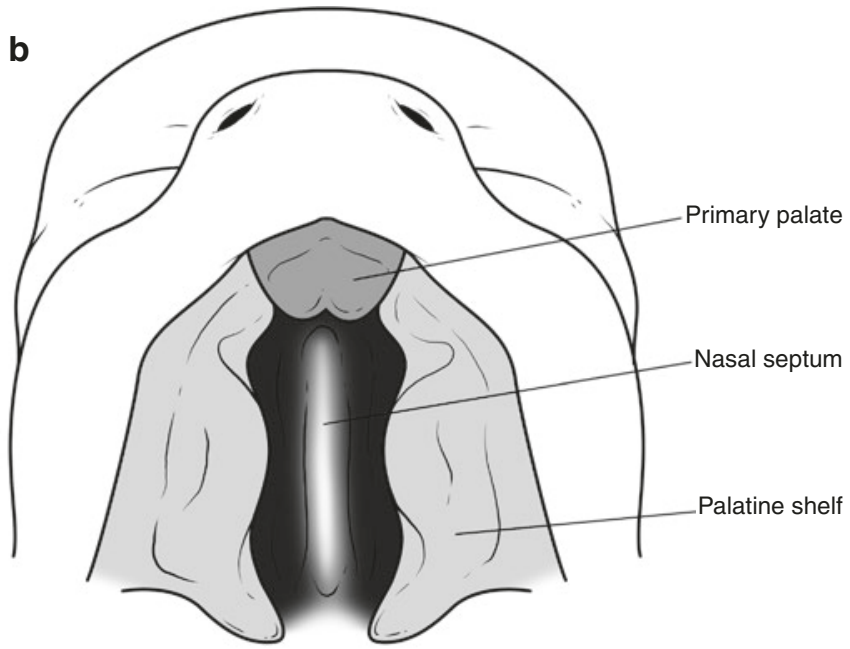

Fig.73.1 (a, b) Embryology of palate-primary palate
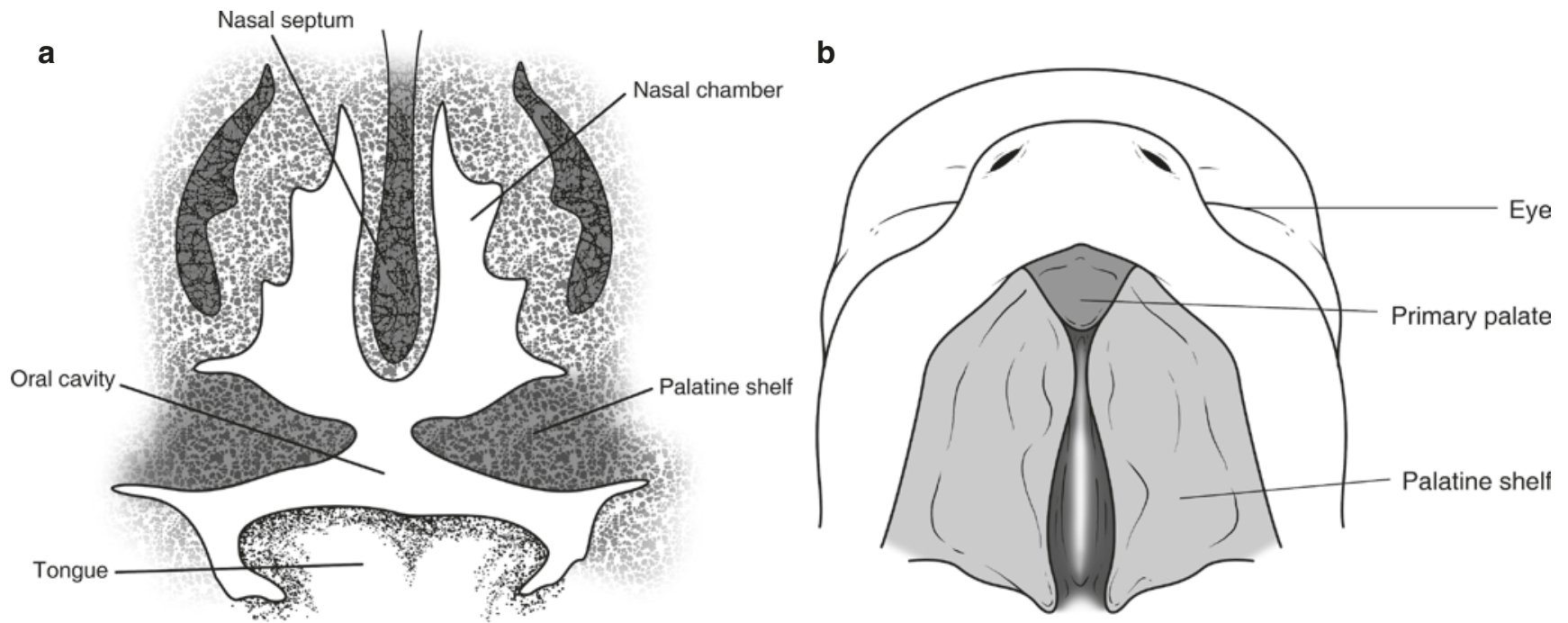

CAssociation of Oral and Maxillofacial Surgeons of India

Fig. 73.2 (a, b) Embryology of palate—secondary palate 


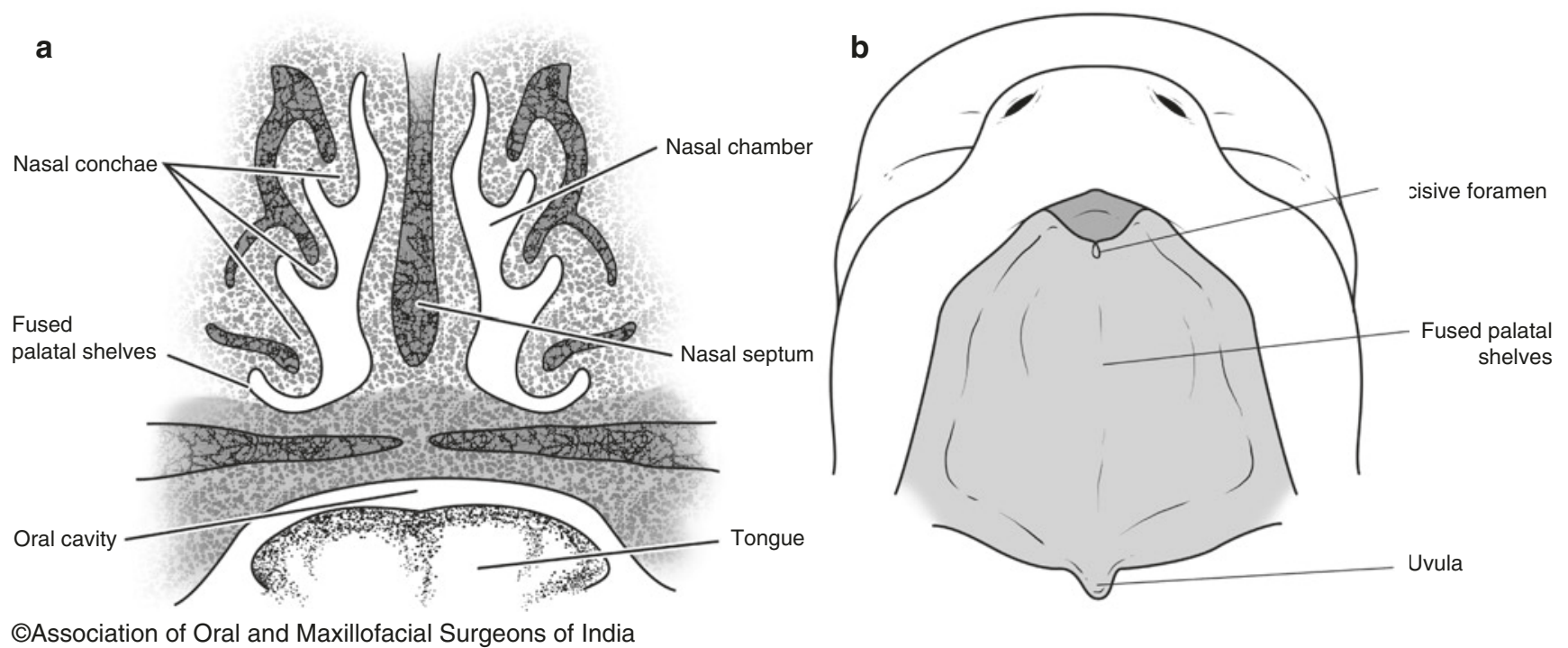

Fig. 73.3 (a, b) Embryology of palate-completion of palate

\subsubsection{Muscles}

The muscles of the soft palate include intrinsic muscle, i.e., musculus uvulae, and the insertions of several extrinsic muscles. Apart from this, large amount of.glandular material is present in the anterior inferior portion of the velum and an anterior aponeurosis. Extrinsic muscles of the velum include the tensor veli palatine, levator veli palatini, palatopharyngeus, palatoglossus, and fibers of the superior constrictor. Pharyngeal muscles usually described as having functional role in velopharyngeal movement include the superior constrictor and the salpingopharyngeus (Fig. 73.4).

Following is a tabular summary for the muscles of palate and their abnormal anatomy in a cleft palate (Table 73.1).

From functional standpoint, it is apparent that the levator veli palatini muscle is the principal and quite possibly the only muscle to function for elevation of the velum in speech. The differences between the normal and the cleft arrangement of the muscles of velopharyngeal closure occur because the muscles extending toward the central line of the soft palate cannot attach themselves in the midline of the velum so they insert at some substitute points. These points prevent the muscles from becoming fully functional, and therefore their development is retarded. With the preservation of normal origins, the atypical insertions and hypoplasia of the muscles are the main pathological features in the cleft palate. The abnormal insertions of levators in clefts illustrate that the function of these muscles in cleft palate is almost opposite to that in normal one. While the muscles of both sides normally join in the raphe to form a sling lifting the palate upward, in cleft palate each muscle pulls its own half of the soft palate in an entirely different direction, i.e., superolaterally, causing further widening of the cleft.

\subsubsection{Vascular Supply (Fig. 73.5a and b)}

The internal maxillary artery gives off the descending palatine artery, which in turn gives off several branches to the tonsils and soft palate. It then passes through the posterior palatine foramen, just above the periosteum, and proceeds forward close to the alveolar margin on each side as the greater major palatine artery to the incisive fossa. At that point it sends terminal branch through the incisive foramen to anastomose with the terminal branch of the sphenopalatine artery. The vascular supply of importance is discussed under two headings, anterior and posterior palate.

\subsubsection{Vascular Supply of the Anterior Palate/ Premaxilla}

The blood supply to the anterior alveolar process of the maxilla comes from the arterial complex composed of the major palatine, anterior and superior alveolar, and branches of the sphenopalatine artery. The posterior septal artery arises from the sphenopalatine artery in the roof of the nasal cavity and courses down the groove of the vomer to the incisive foramen. In the complete bilateral cleft lip and palate, the union of the superior labial arteries is lacking; thus they do not contribute to the blood supply of the philtrum. Also the anastomosis of the posterior septal artery with the major palatine artery is absent. Therefore premaxilla and philtrum must derive their blood supply from the posterior septal artery and to some degree from the lateral and terminal branches of the anterior ethmoid vessels which pass through the columella. There is usually one well-developed vessel on either side of the premaxilla in the region where the incisive foramen should have been. Each of these vessels moves anteriorly and inferiorly into 
Fig. 73.4 Muscles of the palate demonstrated in a complete cleft of the lip, palate and alveolus (bilateral)

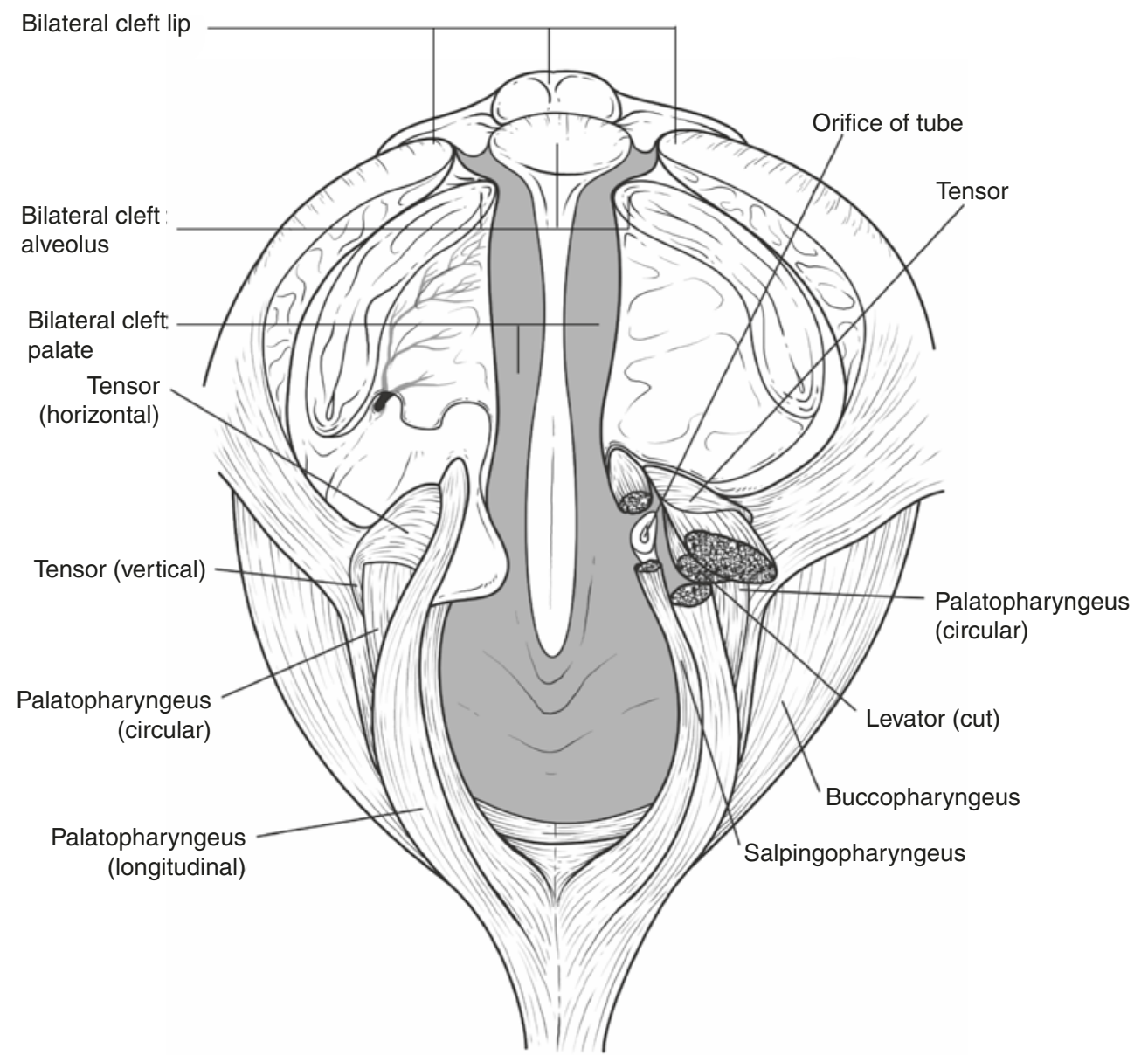

(CAssociation of Oral and Maxillofacial Surgeons of India

Table 73.1 Muscles of soft palate

\begin{tabular}{|c|c|c|c|c|}
\hline Muscle & Origin & Insertion & Function & $\begin{array}{l}\text { Pathological anatomy in } \\
\text { cleft palate }\end{array}$ \\
\hline $\begin{array}{l}\text { Tensor veli } \\
\text { palatini }\end{array}$ & $\begin{array}{l}\text { Originates from the scaphoid } \\
\text { fossa at the base of the } \\
\text { medial pterygoid plate, spina } \\
\text { angularis of the sphenoid and } \\
\text { from the cartilaginous part of } \\
\text { the auditory tube }\end{array}$ & $\begin{array}{l}\text { The muscle descends } \\
\text { anteroinferiorly and winds } \\
\text { around the pterygoid hamulus, } \\
\text { to which some fibers are } \\
\text { attached, and passes into a } \\
\text { tendon that fans out to form } \\
\text { the palatine aponeurosis few } \\
\text { fibers are attached to the } \\
\text { maxillary tuberosity }\end{array}$ & $\begin{array}{l}\text { The main role of the } \\
\text { tensor is to dilate the } \\
\text { Eustachian tube and its } \\
\text { role in speech is } \\
\text { insignificant }\end{array}$ & $\begin{array}{l}\text { In a cleft palate child, the } \\
\text { palatine aponeurosis is } \\
\text { deficient, especially medially }\end{array}$ \\
\hline $\begin{array}{l}\text { Levator veli } \\
\text { palatini }\end{array}$ & $\begin{array}{l}\text { Arises from the petrous part } \\
\text { of the temporal bone and } \\
\text { from the cartilaginous part of } \\
\text { the Eustachian tubes }\end{array}$ & $\begin{array}{l}\text { The muscle descends on either } \\
\text { side, enters the intermediate } \\
40 \% \text { of the soft palate, and } \\
\text { forms a muscular sling with its } \\
\text { counterpart on the other side }\end{array}$ & $\begin{array}{l}\text { When the paired muscle } \\
\text { contracts, it elevates the } \\
\text { soft palate superiorly and } \\
\text { posteriorly to enable } \\
\text { closure of the } \\
\text { velopharyngeal sphincter. } \\
\text { The latter is formed by the } \\
\text { soft palate anteriorly, the } \\
\text { posterior pillars of the } \\
\text { fauces on either side, and } \\
\text { the posterior pharyngeal } \\
\text { wall posteriorly }\end{array}$ & $\begin{array}{l}\text { In a cleft child, as there is } \\
\text { obviously no continuity } \\
\text { across the midline due to the } \\
\text { cleft, there are abnormal } \\
\text { attachments of the levator } \\
\text { muscle to the } \\
\text { palatopharyngeus muscle } \\
\text { posteriorly, to the edge of the } \\
\text { cleft medially, to the tensor } \\
\text { veli palatini, and to the } \\
\text { posterior edge of the hard } \\
\text { palate anteriorly }\end{array}$ \\
\hline
\end{tabular}


Table 73.1 (continued)

\begin{tabular}{|c|c|c|c|c|}
\hline Muscle & Origin & Insertion & Function & $\begin{array}{l}\text { Pathological anatomy in } \\
\text { cleft palate }\end{array}$ \\
\hline Palatopharyngeus & $\begin{array}{l}\text { Has a palatine portion, a } \\
\text { pterygopalatine portion and } \\
\text { the salpingopharyngeal part. } \\
\text { It arises from the lateral and } \\
\text { posterior part of pharynx and } \\
\text { attaches into the velum. Its } \\
\text { superior fibers arise from } \\
\text { complex intermingling with } \\
\text { the superior constrictor } \\
\text { muscle. Lower fibers of the } \\
\text { palatopharyneus arise from } \\
\text { the inferior part of the lateral } \\
\text { wall of the pharynx, medial } \\
\text { to the middle and inferior } \\
\text { constrictor muscles. Some } \\
\text { fibers may arise from the } \\
\text { thyroid cartilage. These lower } \\
\text { fibers pass through the } \\
\text { palatopharyngeal arch to } \\
\text { insert into the velum }\end{array}$ & $\begin{array}{l}\text { It is found in the posterior } \\
\text { pillar of the fauces. The fibers } \\
\text { pass horizontally into the } \\
\text { posterior three fourths of the } \\
\text { soft palate inferior to the fibers } \\
\text { of the levator palatini muscle }\end{array}$ & $\begin{array}{l}\text { The muscle helps to } \\
\text { narrow the velopharyngeal } \\
\text { opening by bringing the } \\
\text { palatopharyngeal arches } \\
\text { together }\end{array}$ & $\begin{array}{l}\text { The muscle is relatively well } \\
\text { developed in the cleft palate } \\
\text { child and ends partly along } \\
\text { the cleft edge and partly along } \\
\text { the posterior edge of the hard } \\
\text { palate. Some fibers pass along } \\
\text { the edge of the cleft along } \\
\text { with the levator to form the } \\
\text { muscle of veau }\end{array}$ \\
\hline Palatoglossus & Arises from the tongue & Inserts into the soft palate & $\begin{array}{l}\text { The paired muscle forms } \\
\text { the anterior part of the } \\
\text { sphincter and narrows the } \\
\text { isthmus. It is antagonistic } \\
\text { to the levator in its action, } \\
\text { drawing the palate } \\
\text { inferiorly }\end{array}$ & $\begin{array}{l}\text { This muscle doesn't play a } \\
\text { major role in cleft palate } \\
\text { anatomy }\end{array}$ \\
\hline Musculus uvulae & $\begin{array}{l}\text { Arises from the posterior } \\
\text { nasal spine and the palatine } \\
\text { aponeurosis }\end{array}$ & $\begin{array}{l}\text { Passes posteriorly along either } \\
\text { side of the midline and inserts } \\
\text { into the junction of the } \\
\text { proximal and middle thirds of } \\
\text { the uvula. The rest of the } \\
\text { uvula contains only mucous } \\
\text { glands }\end{array}$ & $\begin{array}{l}\text { Contraction of the muscle } \\
\text { aids the levator in forming } \\
\text { the levator eminence, } \\
\text { which is a hump like } \\
\text { projection formed } \\
\text { proximal to the uvula and } \\
\text { aids in closure of the } \\
\text { velopharynx during } \\
\text { speech }\end{array}$ & $\begin{array}{l}\text { The presence and extent of } \\
\text { the muscle in a cleft palate } \\
\text { child is disputed. } \\
\text { It is also supposed to be } \\
\text { absent in occult submucous } \\
\text { cleft patients }\end{array}$ \\
\hline $\begin{array}{l}\text { Superior } \\
\text { pharyngeal } \\
\text { constrictor }\end{array}$ & $\begin{array}{l}\text { Quadrangular muscle in the } \\
\text { upper third of the posterior } \\
\text { pharyngeal wall. Origin at } \\
\text { the hamulus and the adjacent } \\
\text { pterygomandibular raphe }\end{array}$ & $\begin{array}{l}\text { Merges with the } \\
\text { palatopharyngeus.. Fibers pass } \\
\text { around and through the lateral } \\
\text { pharyngeal wall, and merge } \\
\text { with the corresponding fibers } \\
\text { of the opposite side forming a } \\
\text { tendinous strip- the pharyngeal } \\
\text { raphe, which runs in the } \\
\text { midline from the pharyngeal } \\
\text { tubercle of the occipital bone } \\
\text { through the entire length of } \\
\text { the pharynx }\end{array}$ & $\begin{array}{l}\text { The upper most fibers are } \\
\text { responsible for the } \\
\text { formation of the } \\
\text { passavant's ridge, which is } \\
\text { a projection on the } \\
\text { posterior pharyngeal wall } \\
\text { during speech. However, } \\
\text { the edge is usually below } \\
\text { the level of closure of the } \\
\text { velopharyngeal sphincter, } \\
\text { and in only about one } \\
\text { third of the patients, it is } \\
\text { believed to contribute to } \\
\text { closure of the sphincter } \\
\text { (the mistake of passavant) }\end{array}$ & \\
\hline
\end{tabular}

the philtrum and forms an arcuate anastomosis across the midline in the inferior part of the philtrum.

\subsubsection{Vascular Supply of Posterior Palate}

The greater palatine artery supplies the oral surface of the hard palate and gives off a few fine branches which perforate the horizontal plate of the maxilla to supply the nasal mucosa. It also sends twigs to the gingiva and the palatoglossal arch. The lesser palatine artery supplies the anterior half of the oral surface of the soft palate. A branch of the facial artery, the ascending palatine artery, is the largest vessel entering the soft palate. It ascends on the lateral side of the superior constrictor muscle to turn downward and forward into the soft palate, between the tensor and levator palati giving small branches to these muscles. Twigs from the tonsillar and ascending pharyngeal arteries also reach the soft palate. In the secondary palate, the existence or absence of cleft makes little difference to the vascular pattern. The palatal mucoperios- 

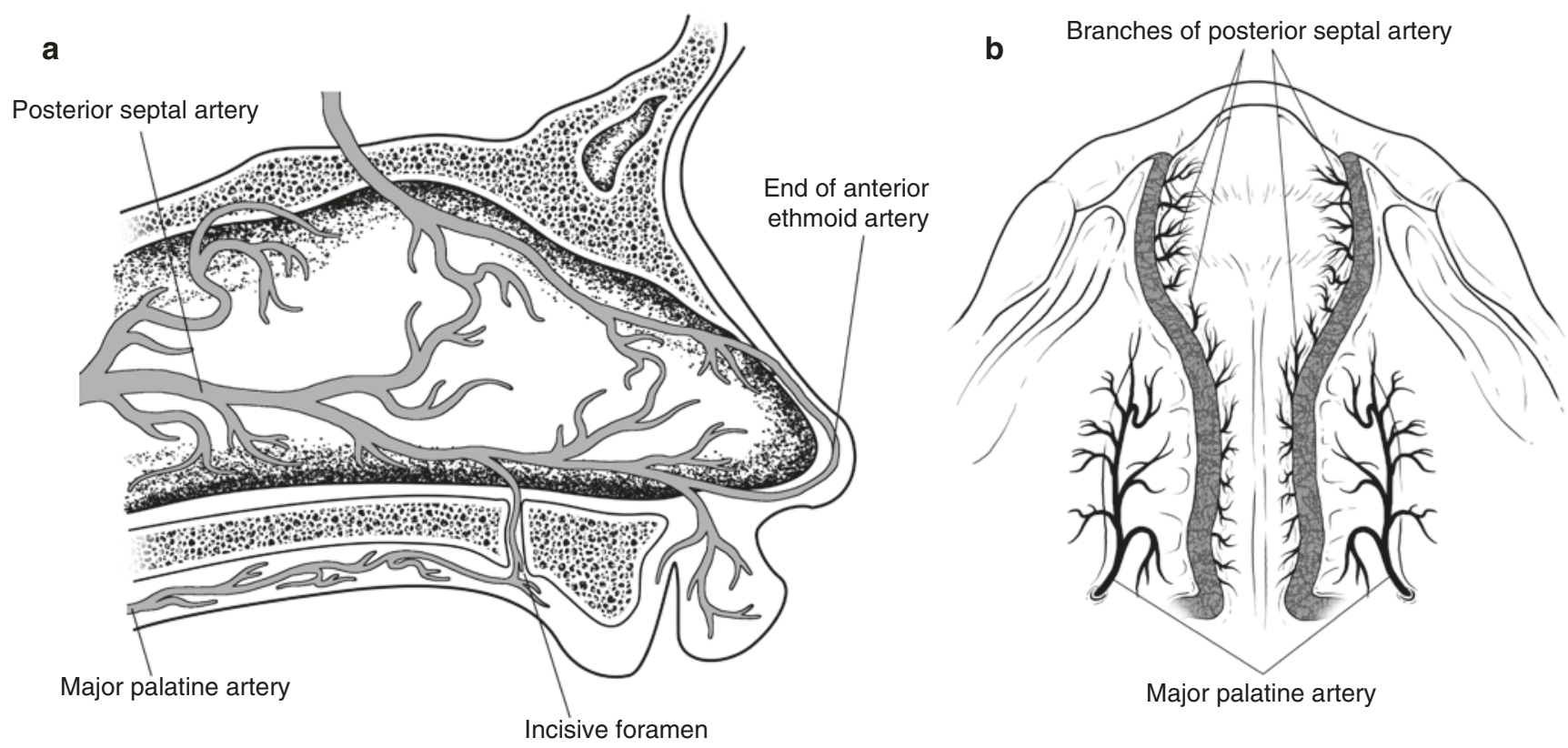

CAssociation of Oral and Maxillofacial Surgeons of India

Fig. $73.5(\mathbf{a}, \mathbf{b})$ Vascular supply of the palate

teum is detached from its bony base in the palatal pedicle flap, and as a result the recurrent bony branches are severed. These branches result in bleeding from their cut stumps at the bony surface. This may be judged insignificant at the time of surgery; however, after the flap is repositioned, should bleeding continue, blood may pool beneath the repositioned flap [17].

\subsection{Classification and Presentations of Cleft Palate}

Many of the historical and contemporary classifications have been discussed in brief in the Chap. 72 on cleft lip. However, Veau's classification for palate is the most practical and therefore is mentioned again here.

Submucous cleft palate exhibits at least one of Calnan's three criteria [17]:

(a) A palpable notch on the posterior border of the hard palate.

(b) Zona pellucida or a bluish tinge in the midline of the soft palate due the paucity of muscle bulk at this level.

(c) Bifid uvula- this may extend from a mere groove on the uvula to complete bifidity.
Table 73.2 Veau's classification of cleft palate

I. Cleft of the soft palate alone

II. Complete cleft of the palate up to the incisive foramen

III. Unilateral complete cleft of the palate and pre-palate. In these the vomer is attached to the maxilla on the non-cleft side

IV. Complete bilateral cleft of the palate and pre-palate. These patients have a protruding premaxilla, and the vomer is in the midline

Victor Veau (1931) has classified cleft palates into four groups [7] (Table 73.2)

Clefts of the palate that are less extensive in magnitude include the submucous cleft palate and the occult submucous in cleft palate.

Sommerlad has devised a grading system for the submucous cleft palate with three points for each of the above criteria [18]. A lesser score in this system naturally denotes more trivial clefting. However, paradoxically a lower score reflects a poorer prognosis for speech according to this study. An occult submucous cleft does not exhibit any of Calnan's criteria but shows a trough-like depression on the superior surface of the soft palate as seen in nasoendoscopy. Croft believed that in these patients, the musculus uvulae is absent. It is suspected when a child with a normal palate speaks with nasal emission. 


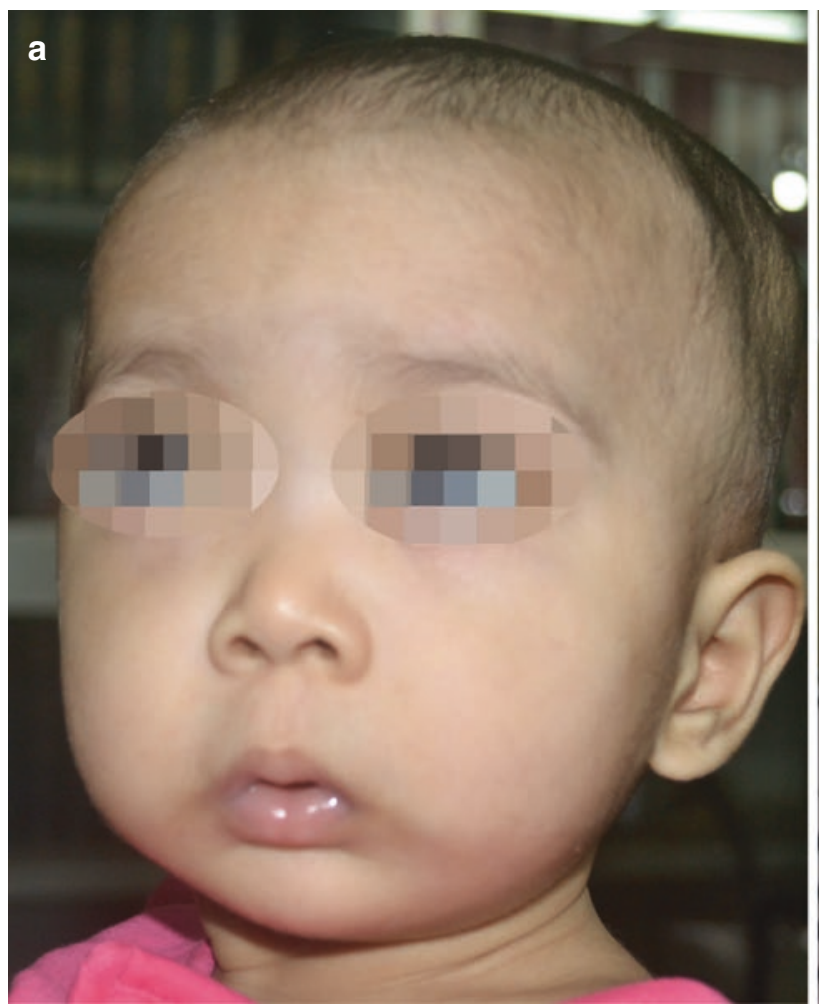

CAssociation of Oral and Maxillofacial Surgeons of India

Fig. 73.6 (a, b) Picture of child with Pierre Robin Sequence

\subsection{Clinical Evaluation of the Cleft Palate Patient}

\subsubsection{General Examination}

A routine per-oral examination of the neonate reveals the cleft of the palate with or without cleft lip. The extent of clefting is noted. General examination is mandatory as it is important to identify syndromic patients. These are more common in isolated cleft palate patients [19]. Pierre Robin sequence is a fairly common presentation with micrognathia or retrognathia (Fig. 73.6 and b). As the bony abnormalities are believed to be the cause of the non-descent of the tongue in utero leading to the clefting of the palate, this is now believed to be a sequence and not a syndrome. Syndromic patients include Treacher Collins syndrome, Goldenhar syndrome, etc.

\subsubsection{Clinical Assessment of the Cleft}

The first clinical visit usually happens soon after birth. The extent cleft is assessed, i.e., the length of the palate and the

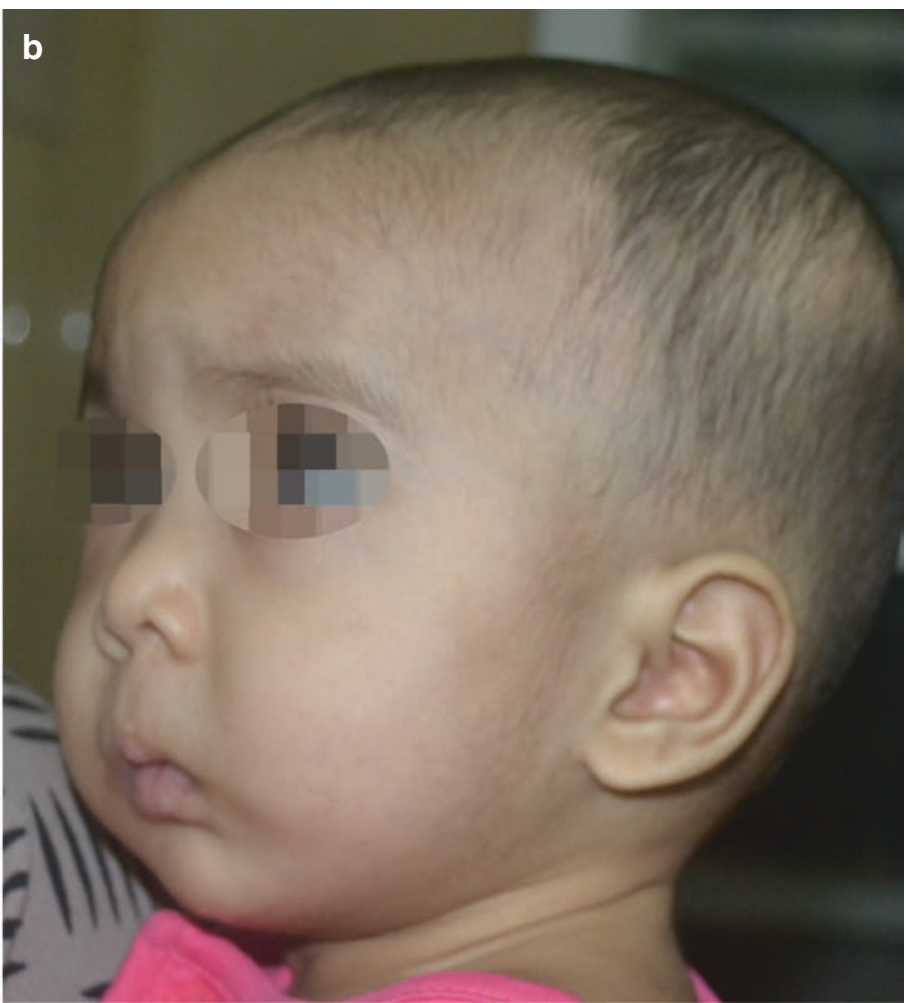

b

width of the cleft. Randall has classified cleft palate on the basis of length into four types [20]. Clefts may be partial or complete. A partial cleft of the secondary palate is confined to the soft palate (Fig. 73.7).

A complete cleft includes both the soft and the hard palate up to the incisive foramen (Fig. 73.8). In patients with bilateral cleft lips, the associated cleft palate usually presents with a central vomer and clefting on either side of the vomer (Fig. 73.9).

A pediatric assessment is made for other anomalies, weight of the baby is noted, and feeding instructions are given during this visit. A squeezable feeding bottle is usually advisable to overcome child's difficulties in sucking. The child is fed with the head held slightly higher. Parents are counselled about the need for immunization. They are also explained about the need for surgery and are shown results of the procedure on similar patients. It is very important to allay their anxiety as they are very often crestfallen on seeing the deformity in their baby. Subsequent visits, possibly at monthly intervals, aim to assess the growth and development of the baby. Associated cardiac or other anomalies if present need investigation. 


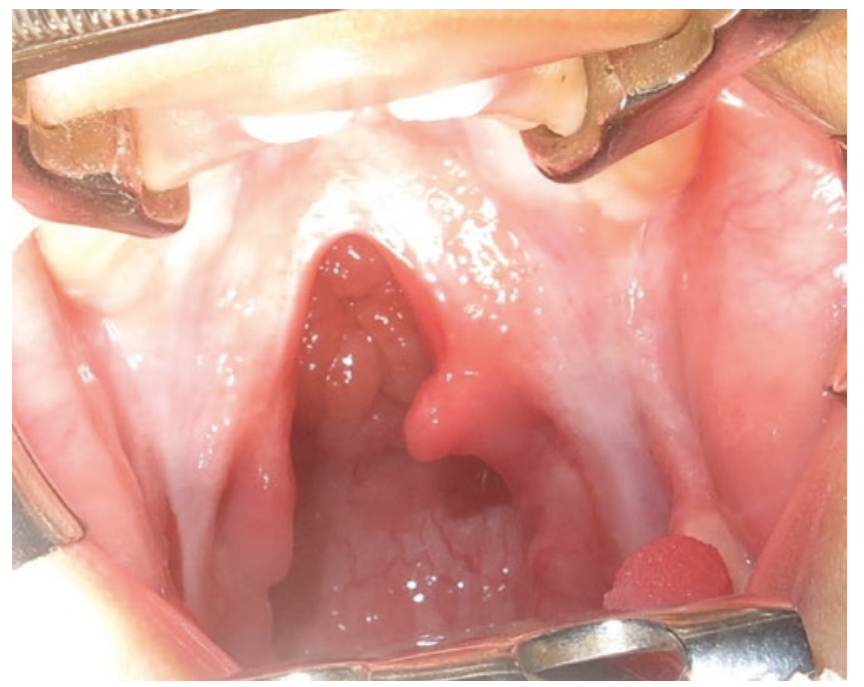

CAssociation of Oral and Maxillofacial Surgeons of India

Fig. 73.7 A child with partial cleft palate

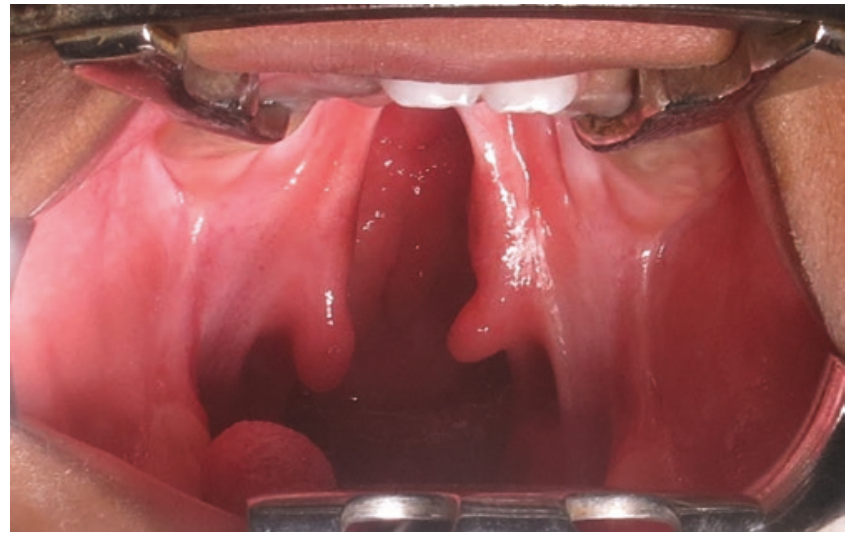

CAssociation of Oral and Maxillofacial Surgeons of India

Fig. 73.8 A child with complete cleft palate

\subsubsection{Imaging and Other Investigations}

Routine imaging is not generally practiced in the evaluation of cleft palate patients. Syndromic patients require other investigations as part of the various manifestations of their syndromes. For instance, children with velocardiofacial syndrome may require echocardiogram in view of the associated cardiac anomalies. Children with delayed development, microcephaly, etc. will require neurological assessment and will usually need an MRI of the brain. Rarely a child may have a meningoencephalocele presenting behind the palate. MRI has been used to evaluate submucous clefts with a view to help in the planning of the management. If it can be shown that there is not adequate muscle continuity across the midline, an early decision can be taken to operate on the child at the usual time of cleft palate repair. On the other hand, if there is good muscle across the midline, these repairs can be

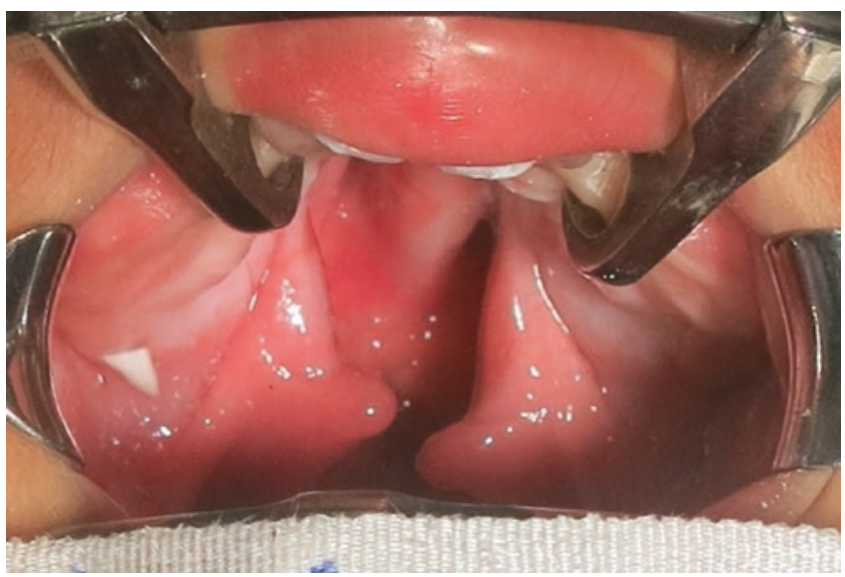

CAssociation of Oral and Maxillofacial Surgeons of India

Fig. 73.9 A child with bilateral cleft palate

justifiably delayed until the development of speech. MRI has also been used to assess the Eustachian tube function. Hearing assessment should be mandatory in all cleft palate patients.

\subsection{Preoperative Factors (Box 73.1)}

\section{Box 73.1 Preoperative Considerations}

- Timing of repair.

- One stage or two stage repair.

- Anatomy of the cleft.

- Airway.

- Feeding.

- Pediatric consultation.

- Cardiac consultation.

- Neuro consultation.

- Ent consultation.

- Anesthesia.

1. Timing and Age of the Patient.

The dilemma regarding the timing of repair is between earlier repair with better prognosis for speech, but worse prognosis for maxillary growth, and late repair which is exactly the opposite. Most surgeons today agree that the cleft palate is to be operated close to 1 year. Some prefer 9 months, where others wait for up to a year and 4 months. At our center we have been operating on these children at about 11 months of age. The Oslo school of surgeons [21, 22] devised a protocol of operating on the lip with the soft palate in the first stage and operating on the hard palate much later. In some centers, the palate has been repaired 
first at initial presentation, and the cleft lip is repaired, subsequently, in view of the fact the children may not be brought back for treatment of the palate once the lip is repaired [23].

2. Airway.

Airway management is important at the time of birth in cleft palate patients, as most of isolated cleft palates may be associated with a smaller airway at birth. This may be due to associated sequence or syndromes, such Pierre Robin sequence or Treacher Collins syndrome. Such patients might require emergency tracheostomy or tongue lip adhesion to secure airway. Definitive management for mandibular advancement and cleft palate repair can be undertaken at a later stage.

3. Feeding.

As mentioned already, the parents are counselled about feeding practices during the first visit itself. Expressed breast milk is to be preferred. Special feeding bottles like the Haberman feeding bottle are used when the common methods like the use of simple squeezable bottles are not effective. As a cleft child swallows air along with the milk, frequent burping is essential to avoid regurgitation of feeds.

4. Anesthesia.

The operation is performed under general anesthesia with an endotracheal tube. RAE tubes are preferred for cleft palate patients. Previously, Oxford red rubber tubes were used. These were well adapted to the needs of the cleft children but often caused laryngeal edema presumably due to the latex in the tubes. At our center we have given up the use of these otherwise very useful tubes.

Preoperatively, the child must be assessed by a good pediatrician and also by a senior anesthetist. Respiratory infections are common in these children and must be treated if significant. X-ray of the chest is usually done to rule out heart or lung anomalies. Cardiology clearance is required when there are suspected cardiac anomalies. We have come across one case with a congenital absence of the lung.

The anesthetist should be experienced in pediatric anesthesia. In patients with Pierre Robin sequence or other anomalies like shoulder or spinal anomalies, difficult intubation is to be anticipated, and appropriate equipment such as intubating endoscopes, etc. should be at hand, and the anesthetist must be familiar with its use.

\subsection{Principles and Methods of Repair}

There are various surgical techniques described in literature. The techniques have been mentioned (Box 73.2), with the author's surgical technique described in detail (Figs. $73.23,73.24,73.25,73.26,73.27,73.28,73.29,73.30$, and $73.31)$
The major objectives of a cleft palate operation are:

- To produce anatomical closure of the defect.

- To create an apparatus for development and production of normal speech.

- To minimize the maxillary growth disturbances.

The basic principles of cleft palate repair are:

- Closure of the defect.

- Repositioning of the abnormal position of the muscles of the soft palate.

- Reconstruction of the muscle sling.

- Favorable retro positioning of the soft palate and uvula so as to achieve velopharyngeal closure during speech.

- Last and most important is tension-free suturing $[24,25]$.

Box 73.2 Methods of Cleft Palate Repair

Methods of repair

- Von Langenbeck's bipedicle flap technique (Fig. 73.10).

-Veau-Wardill-Kilner Pushback technique (Fig. 73.11).

- Bardach's-Pinto-Wardill two-flap technique.

- Furlow double opposing Z-Plasty.

- Two-stage palatal repair.

- Whole in one repair.

- Palatoplasty.

- Alveolar extension palatoplasty (AEP).

- Primary pharyngeal flap.

- Intravelar veloplasty.

- Vomer flap.

- Buccal myomucosal flap.

73.7 Surgical Technique (Figs. 73.12, 73.13, $73.14,73.15,73.16,73.17,73.18,73.19$, $73.20,73.21,73.22,73.23,73.24,73.25$, $73.26,73.27$, and 73.28 )

Once intubated, the child is placed with the neck extended for adequate visualization of the palate. A pillow under the shoulder helps in this positioning. A suitable mouth gag is used. We use the Dott's gag (Fig. 73.12) with the Kilner suture carrier. A popular gag used widely is the Dingman's gag.

Infiltration: A solution of lignocaine with 1 in 200,000 adrenaline is infiltrated under the mucoperiostem of the hard 


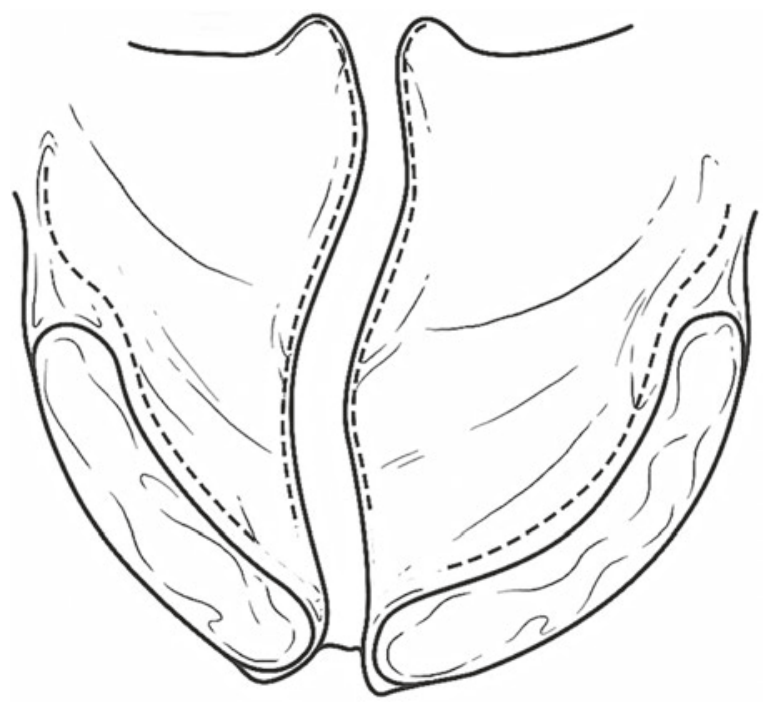

CAssociation of Oral and Maxillofacial Surgeons of India

Fig. 73.10 Langenbeck procedure. Incisions are placed to raise flaps which remain attached in the anterior palatal region

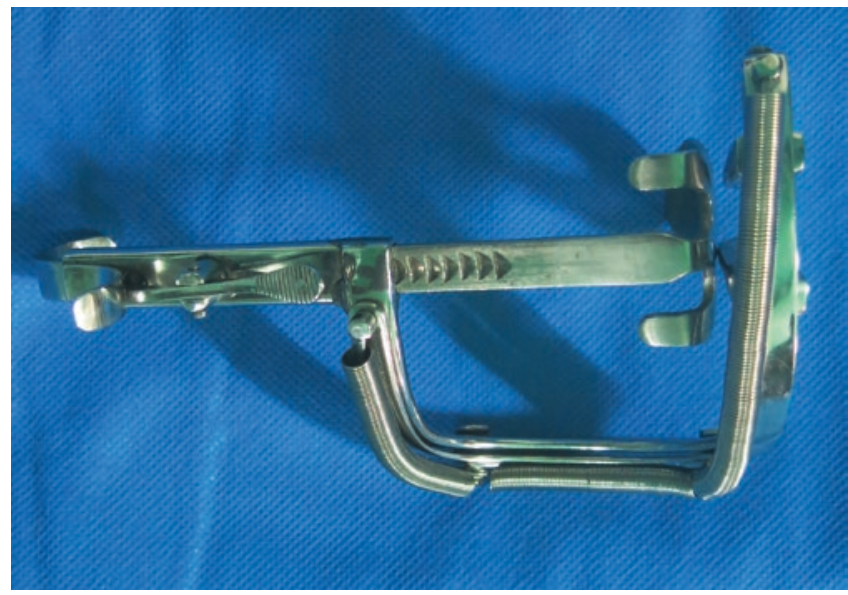

CAssociation of Oral and Maxillofacial Surgeons of India

Fig. 73.12 Dott's gag

palate and above the nasal mucosa in the soft palate. A dental syringe with a short-beveled needle is very useful for this purpose.

Surgical procedure: At our center, we use the two longflap technique popularized in India by Charles Pinto and the world over by Bardach (Fig. 73.13). The technique was originally used by Veau. The cleft edges are pared (Fig. 73.14).

The lateral incision is made from the maxillary tuberosity area toward the retromolar area posteriorly. The pterygoid hamulus is dissected, fractured, and detached (Fig. 73.15a and b).

This aids in mobilization of the nasal layer subsequently. However, there are many surgeons nowadays

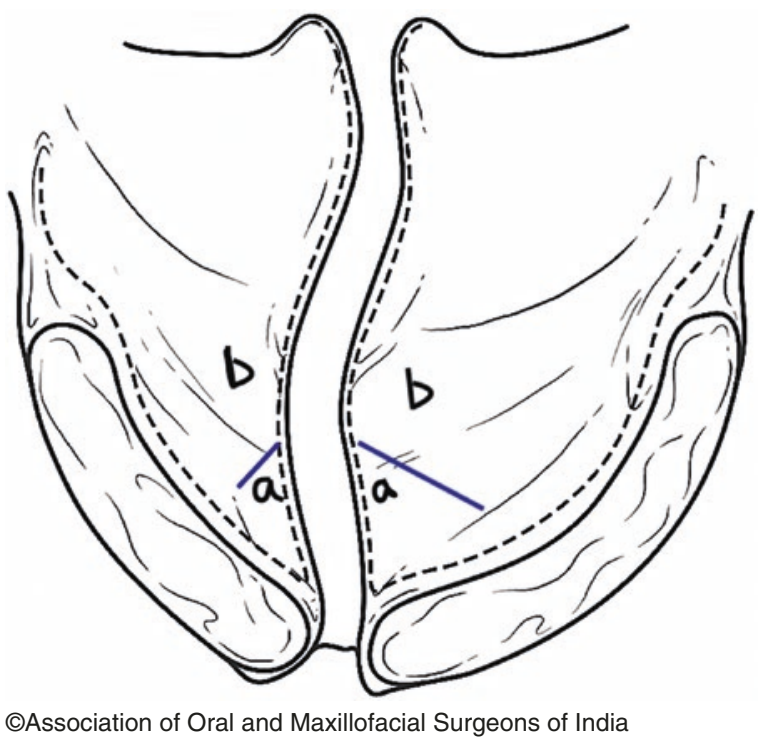

Fig. 73.11 Wardill's four flap palate repair. (a) are the anterior flaps while (b) form the posterior flaps that are closed in a "V to $\mathrm{Y}$ " fashion to gain length for the "push-back"

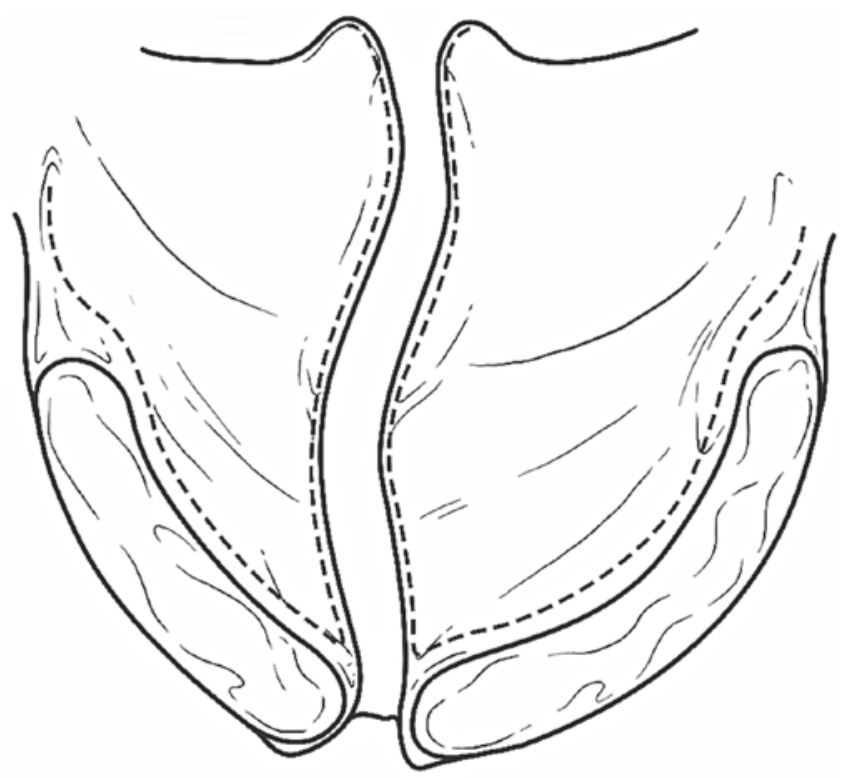

CAssociation of Oral and Maxillofacial Surgeons of India

Fig. 73.13 Pinto Wardill (Bardach) two long-flap procedure. Classical method of raising two flaps detached at the anterior pedicled on the greater palatine artery

who do not believe in fracturing the hamulus. It has, however, been shown in different studies that fracture of the hamulus does not cause any deleterious effects on hearing [26].

The lateral incision is then carried anteriorly and the oral mucoperiosteal flap is lifted off till the medial edge of the hard palate using Kilner's palate elevators (Fig. 73.16a and $b$ ). 
An incision is then made on the medial border of the hard palate, and the flap is also divided anteriorly taking care to secure the end of the greater palatine vessels. The oral flap is then raised till the posterior border of the hard palate. Laterally, the greater palatine vessel is identified and skeletonized, after incising the cone of periosteum which binds the vessel behind it (Fig. 73.17a, b, c and d).

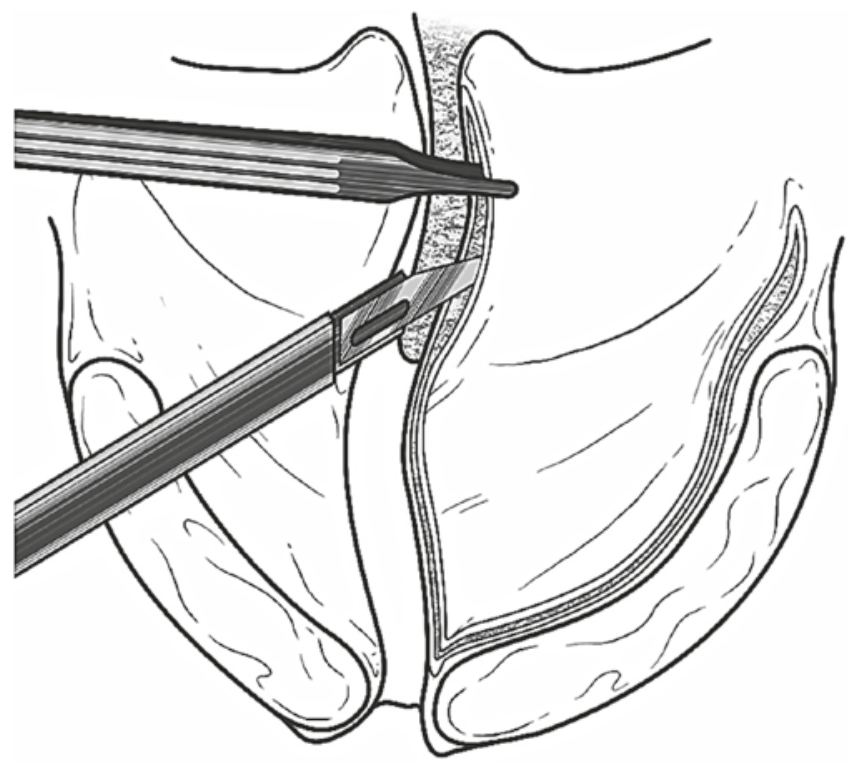

CAssociation of Oral and Maxillofacial Surgeons of India

Fig. 73.14 Pared cleft edges

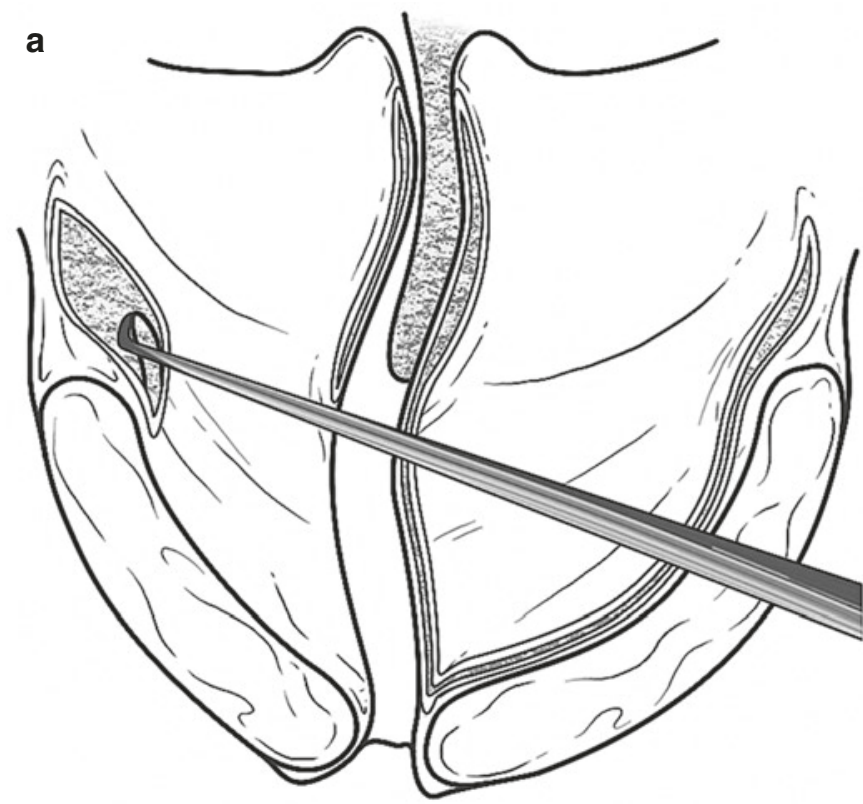

CAssociation of Oral and Maxillofacial Surgeons of India
After the hamulus is fractured, the medial pterygoid plate is denuded of any soft tissue attachments (Fig. 73.18).

Similarly, the posterior border of the hard palate is also cleared of muscular attachments (Fig. 73.19a and b).

A Cumine Scaler is introduced over the bare medial pterygoid plate and then turned anteriorly to separate the nasal layer from the hard palate in one clean sweep. This dissection is then completed on a deeper plane with a Wallace's finisher (Fig. 73.20a and b).

This practice of separating the nasal layer from behind forward was originally introduced by Kilner [8] but has somehow not been followed widely. It is much easier than the alternative method of separating the nasal layer from the hard palate starting anteriorly. Very often this results in tearing of the nasal layer.

Similar dissection is performed on the other side also, raising a long oral mucoperiosteal flap. The vomer flap is raised (Fig. 73.21) and used when accessible and necessary.

Rarely, the vomer is receding and cannot be used. In a bilateral cleft lip patient, the vomer is in the midline, and a central incision on the vomer is made to raise two mucoperiosteal flaps, one on each side, to be sutured to the corresponding side in nasal layer of the hard palate.

Fig.73.15 (a, b) Fracture of the pterygoid hamulus

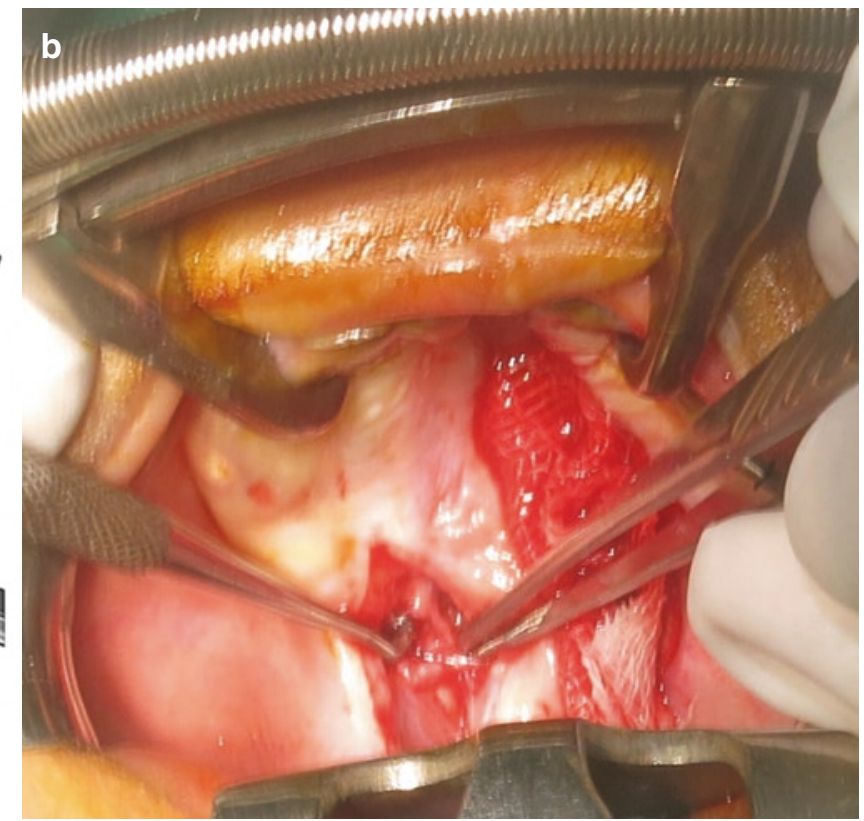




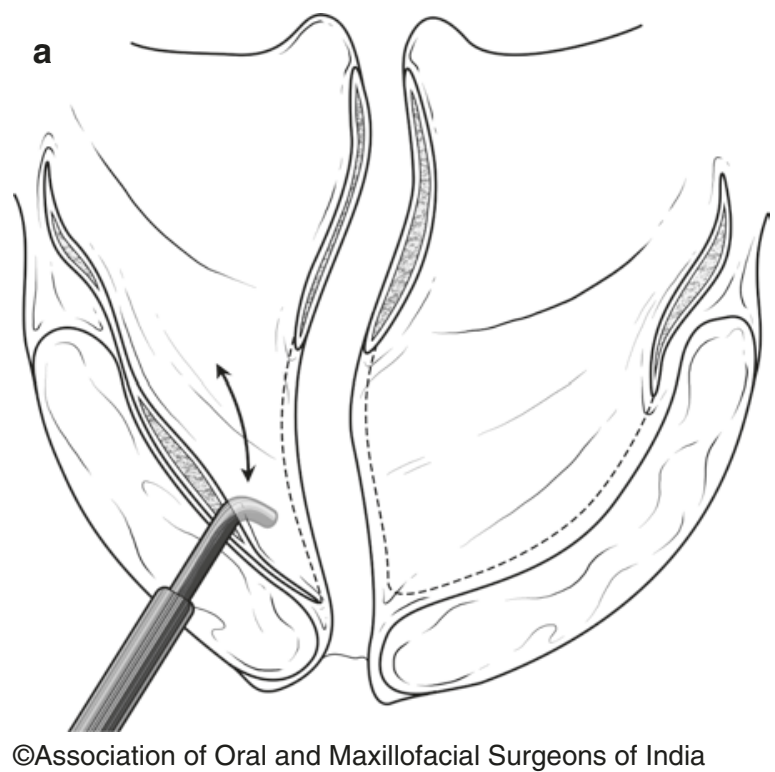

Fig.73.16 (a, b) Elevation of the oral flap with Kilner's elevator

\subsubsection{Dissection of the Soft Palate}

The early techniques of cleft palate repair only detached all false attachments of muscles from the posterior border of the hard palate (Fig. 73.22).

Surgeons like Braithwaite [27] and Kriens [28] emphasized the importance of the dissection and retroposition of the levator veli palati muscle. This was popularized by Sommerlad [29] and Tambewekar in India.

Infiltration of lignocaine with 1:200,000 adrenaline is made between the nasal mucosa and the muscle (Fig. 73.23).

A transverse incision is made on the aponeurotic layer just beyond the hard palate (Fig. 73.24).

Then the muscle is dissected off the underlying mucosa leaving behind enough tissue on the nasal layer, to avoid its tearing during suturing. Also, a narrow layer of muscle is retained along the cleft edges to hold the sutures. The muscle is dissected till just short of the uvula. The muscle contains the levator veli palati mostly. However, it also contains other muscles like the palatopharyngeus ("muscle of Veau") (Fig. 73.25).

The extent of dissection of the muscle on the soft palate varies. The authors [30] only separate it from the nasal layer. Others like Sommerlad [29] also separate it off the oral layer. However, if there is any suspicion of injury to the greater palatine vessels during dissection, then the levator muscle should not be dissected free of the oral mucosa.

\subsubsection{Suturing}

Suturing commences on the nasal layer from anteriorly, proceeding backward. The sutures are not tied but held on the Kilner suture carrier.

\subsubsection{Uvula}

The last suture on the nasal layer is a mattress suture (Fig. 73.26) [30].

Next, an apical mattress suture is placed on the tip of the uvula, and this suture is left long and held on an artery forceps, thus turning the uvula over, providing access to the nasopharyngeal aspect of the uvula. Two or three simple sutures are placed between the mattress suture and the apical stitch (Fig. 73.27a).

Then two or three mattress sutures are placed on the oral aspect of the uvula (Fig. 73.27b).

The nasal layer sutures are then tied from behind forward.

"A" suture: this is the suture placed at the junction of the hard and soft palate. It goes through the nasal mucosa and later crisscrosses into the oral mucosa, resembling the letter A, but is like the figure of " 8 " when tied.

Anterior sutures are also tied but retained long.

Suturing of the oral layers then proceeds from behind forward, with every suture picking up a bite on the nasal layer to obliterate dead space. The dissected levator mus- 


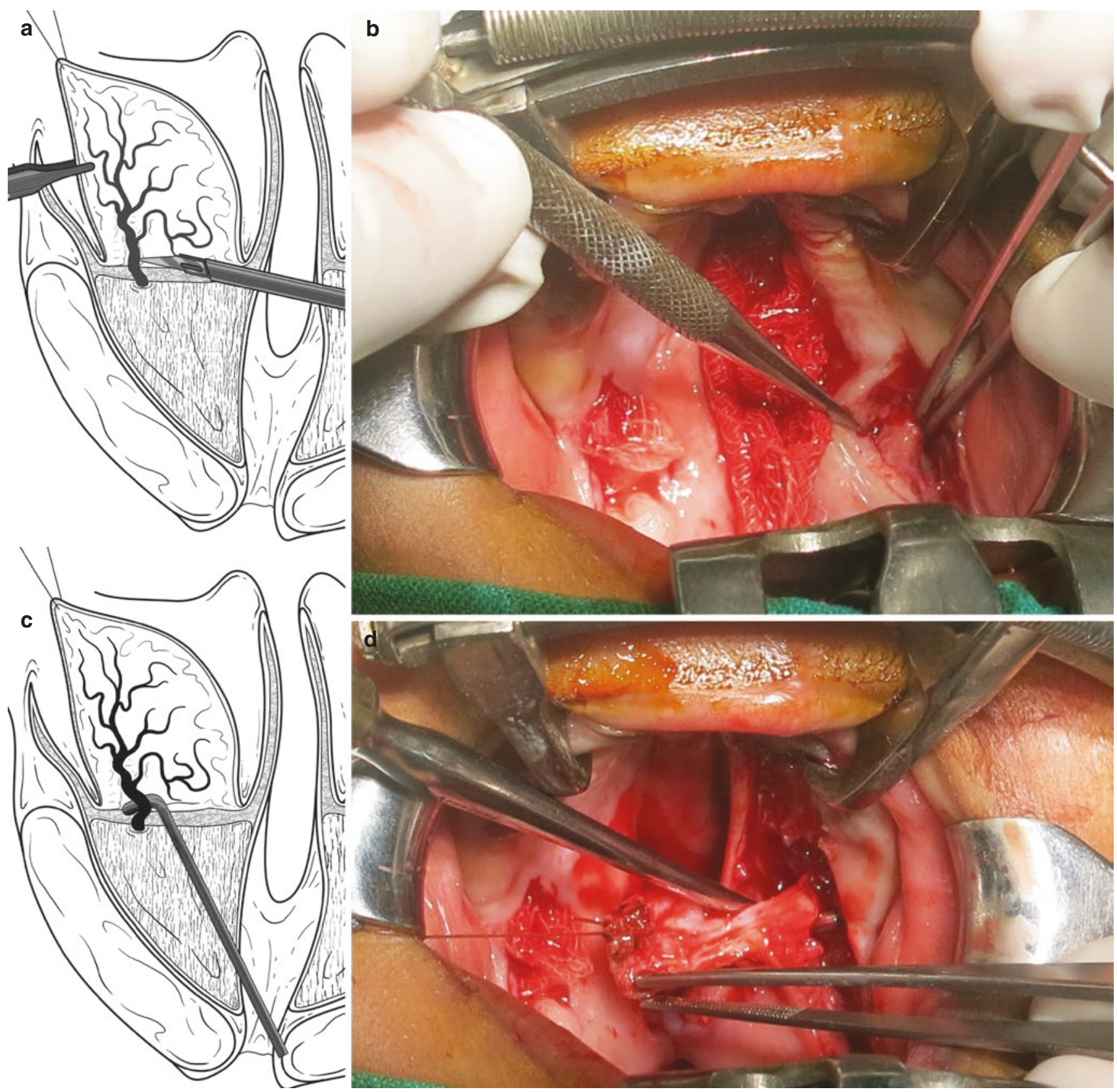

(C)Association of Oral and Maxillofacial Surgeons of India

Fig. 73.17 (a, b) Incising the Periosteal cone to free the greater palatine artery. (c, d) Hooking out the greater palatine vessels (the vessel is pulled out like a bird pulls a worm out of the ground). This reduces the tension on the flaps on suturing 


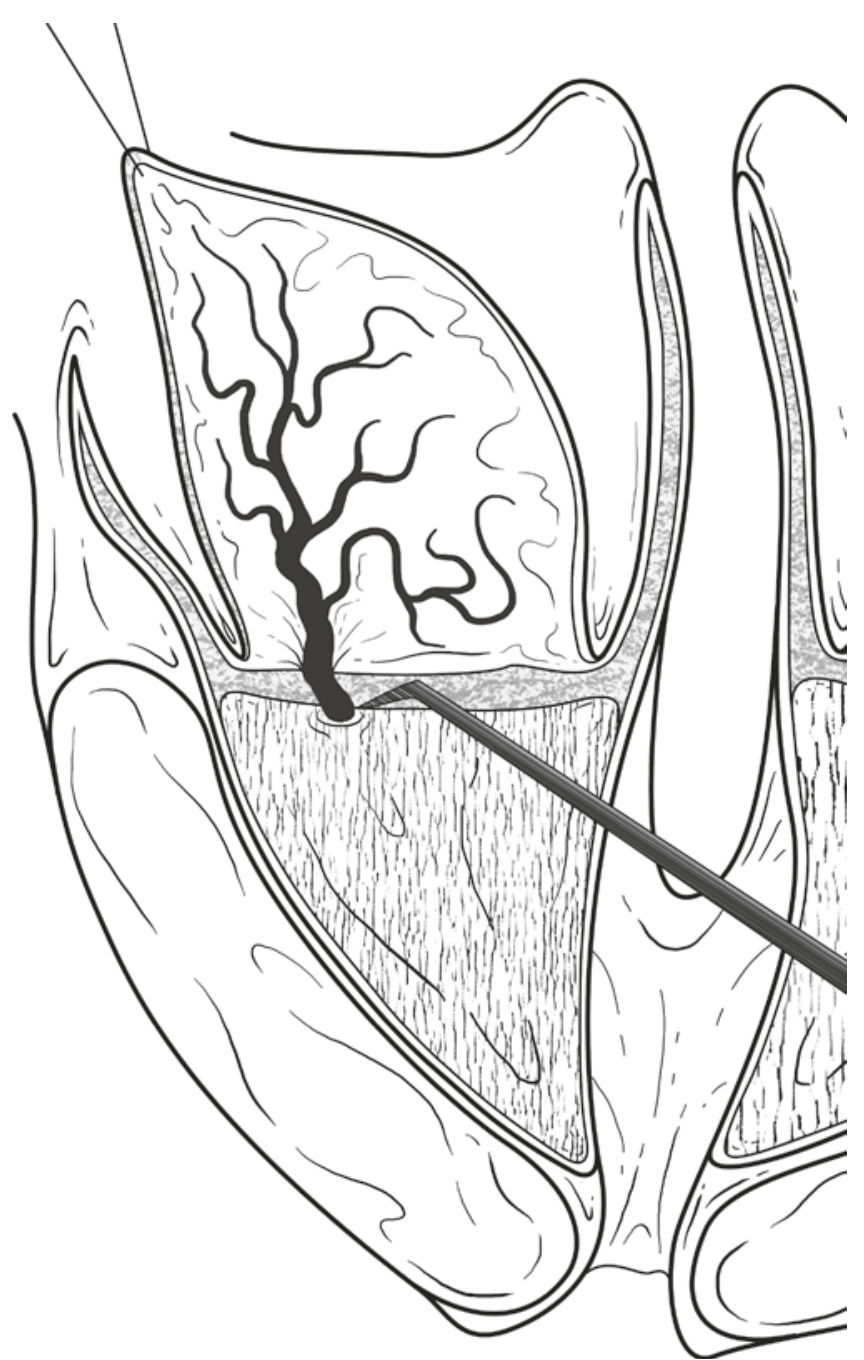

CAssociation of Oral and Maxillofacial Surgeons of India

Fig. 73.18 Medial pterygoid plate dissection

cle is also included in these oral sutures. Some surgeons close the levator muscle as a separate layer. The anterior sutures are then brought through the oral layer also, helping in anchoring the oral layer. In the absence of the anchoring, the oral layer may sag postoperatively causing a "fallen palate."

Laterally the raw areas are sutured with interrupted sutures without tension. This helps in hemostasis (Fig. 73.28).

Previously, this area used to be packed with different materials, but there was often bleeding from the areas on removal of the pack postoperatively.

Buccal pad of fat harvested through a stab incision on the buccal aspect bilaterally has also been used to fill large lateral raw areas.

\subsection{Complications: (Box 73.3)}

\section{Box 73.3 Complications}

Immediate complications.

- Haemorrhage.

- Respiratory obstruction.

- Hanging palate.

- Dehiscence of the repair.

- Oronasal fistula formation. Late complications.

- Bifid uvula.

- Velopharyngeal incompetence.

- Abnormal speech.

- Maxillary hypoplasia.

- Dental malpositioning and malalignment.

- Otitis media.

\subsubsection{Early Complications}

\section{Hemorrhage}

This is often from the apices of the long flaps, from the cut ends of the greater palatine vessels. Arterial bleeding points need to be ligated or cauterized using diathermy. Small venous bleeding areas can be controlled by the use of pressure with fingers or by the use of crushed ice or topical hemostatic agents like tranexamic acid.

\section{Respiratory Obstruction}

This may be from tongue fall and can be avoided by use of a tongue stitch at the time of palate repair. The tongue stitch has to be placed well posteriorly and must include a good bulk of the tongue tissue to avoid the sutures from tearing through.

When a wide cleft palate is closed, the child may have difficulty in learning to breathe adequately through the nose. Laryngeal edema due to endotracheal tube-related trauma may present with a hoarse cry and, in severe cases, chest retraction. Early detection is important, and this can be reversed by intravenous steroids and nebulization.

\section{Breakdown of the Repair}

It may result in fistulas or complete breakdown of the repair. The most common cause of these, especially at the junctional area, is suturing of the cleft edges under tension due to inadequate mobilization. 

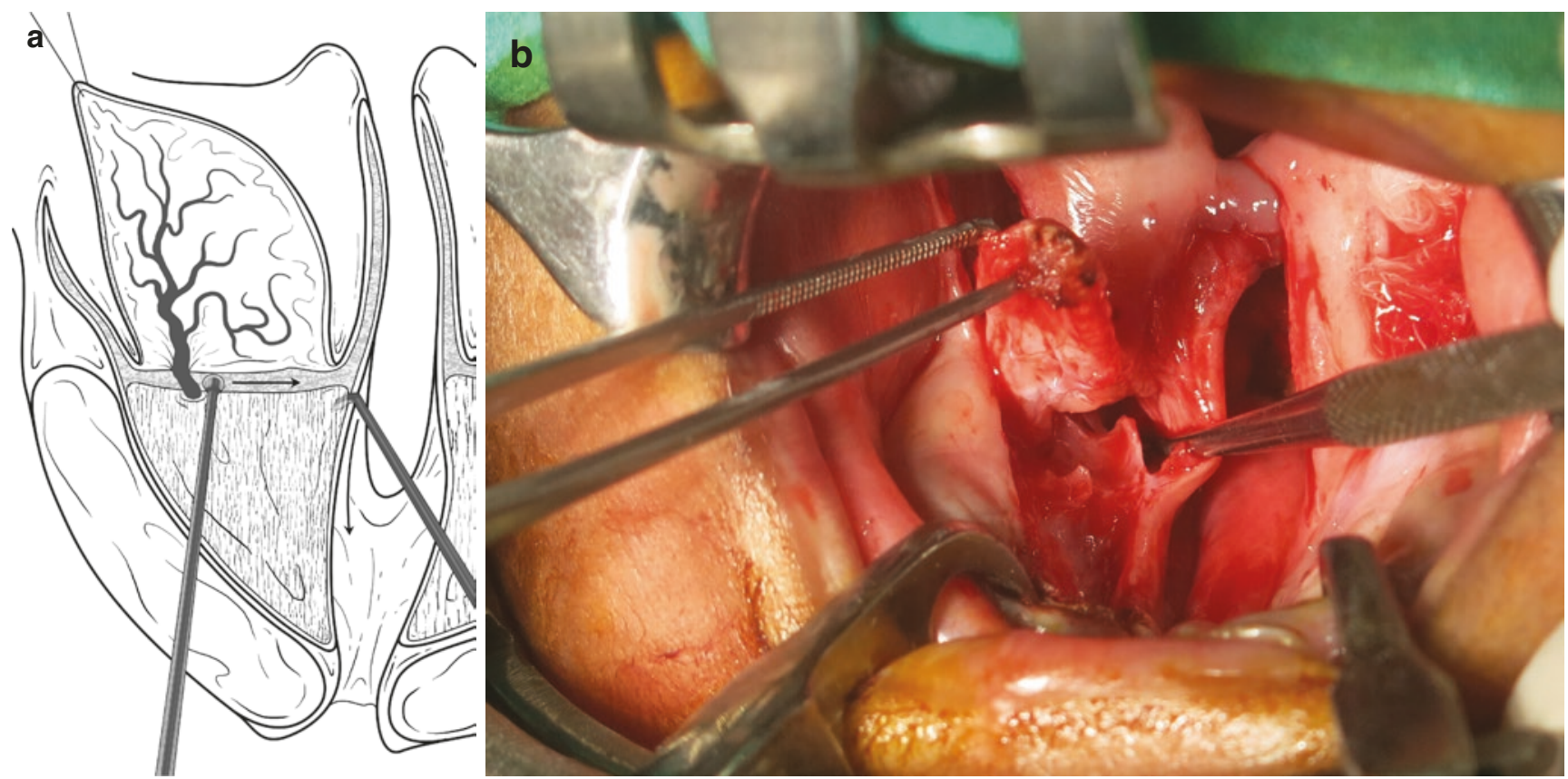

(C)Association of Oral and Maxillofacial Surgeons of India

Fig. 73.19 (a, b) Dissection of the posterior end of the hard palate
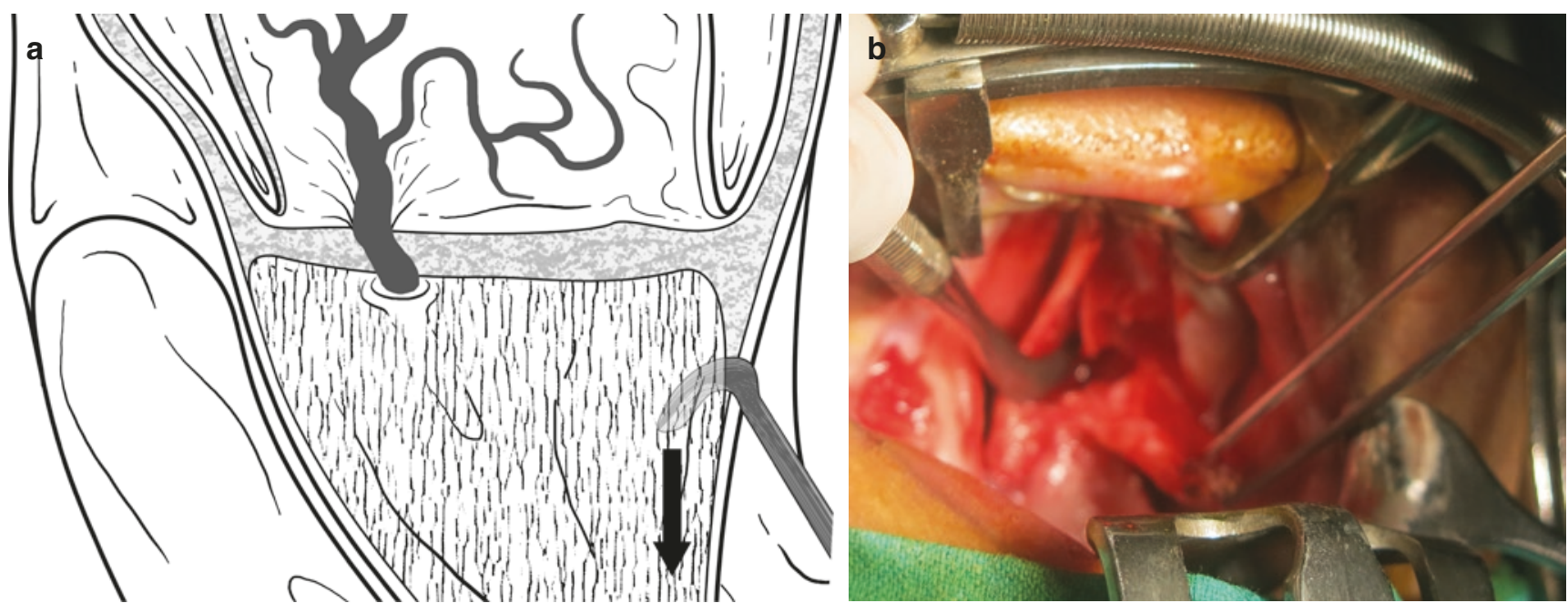

(C)Association of Oral and Maxillofacial Surgeons of India

Fig. 73.20 (a, b) Completion of nasal layer dissection with Wallace's Finisher 


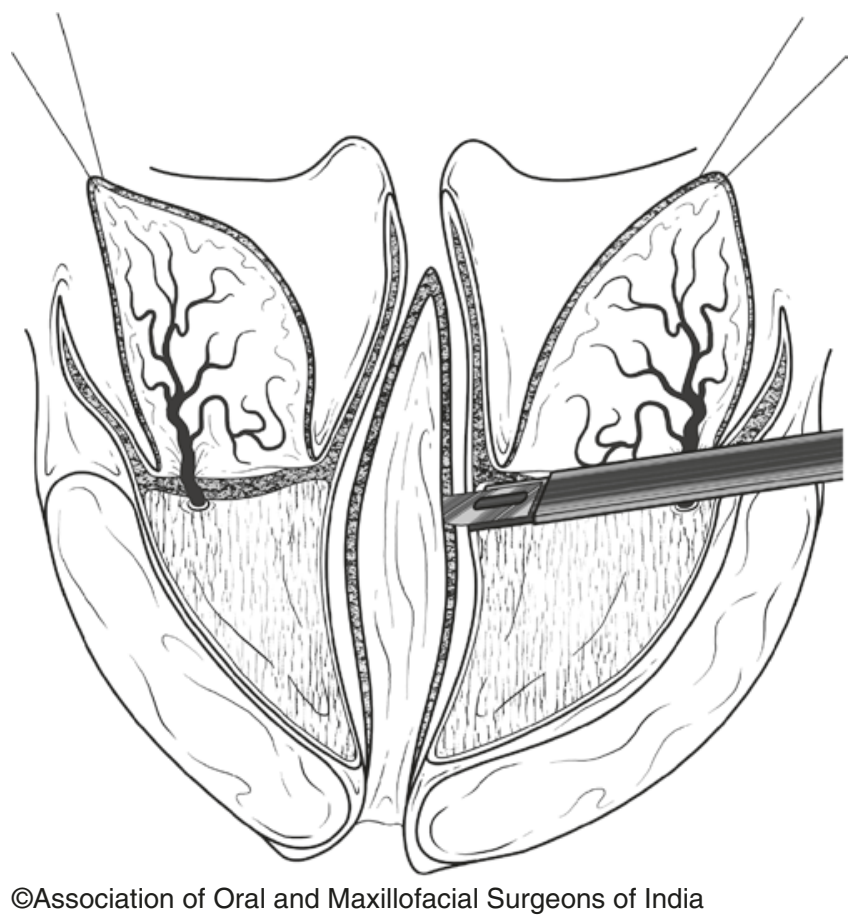

Fig. 73.21 Posterior incision on the vomer

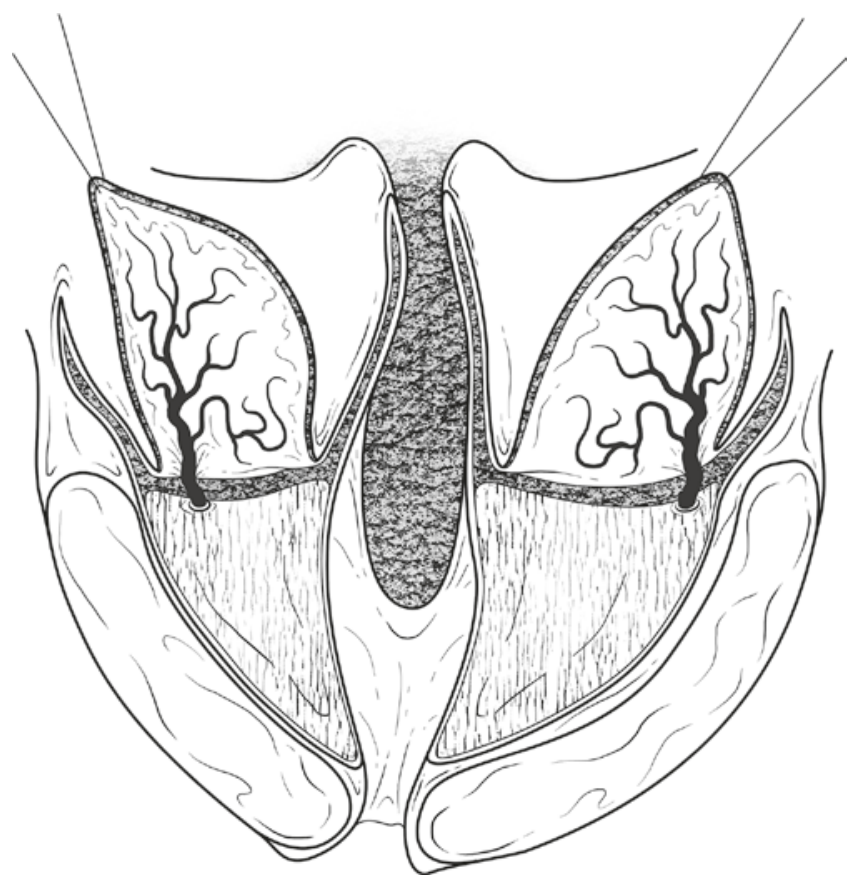

CAssociation of Oral and Maxillofacial Surgeons of India

Fig. 73.22 Complete dissection of the oral and nasal layers

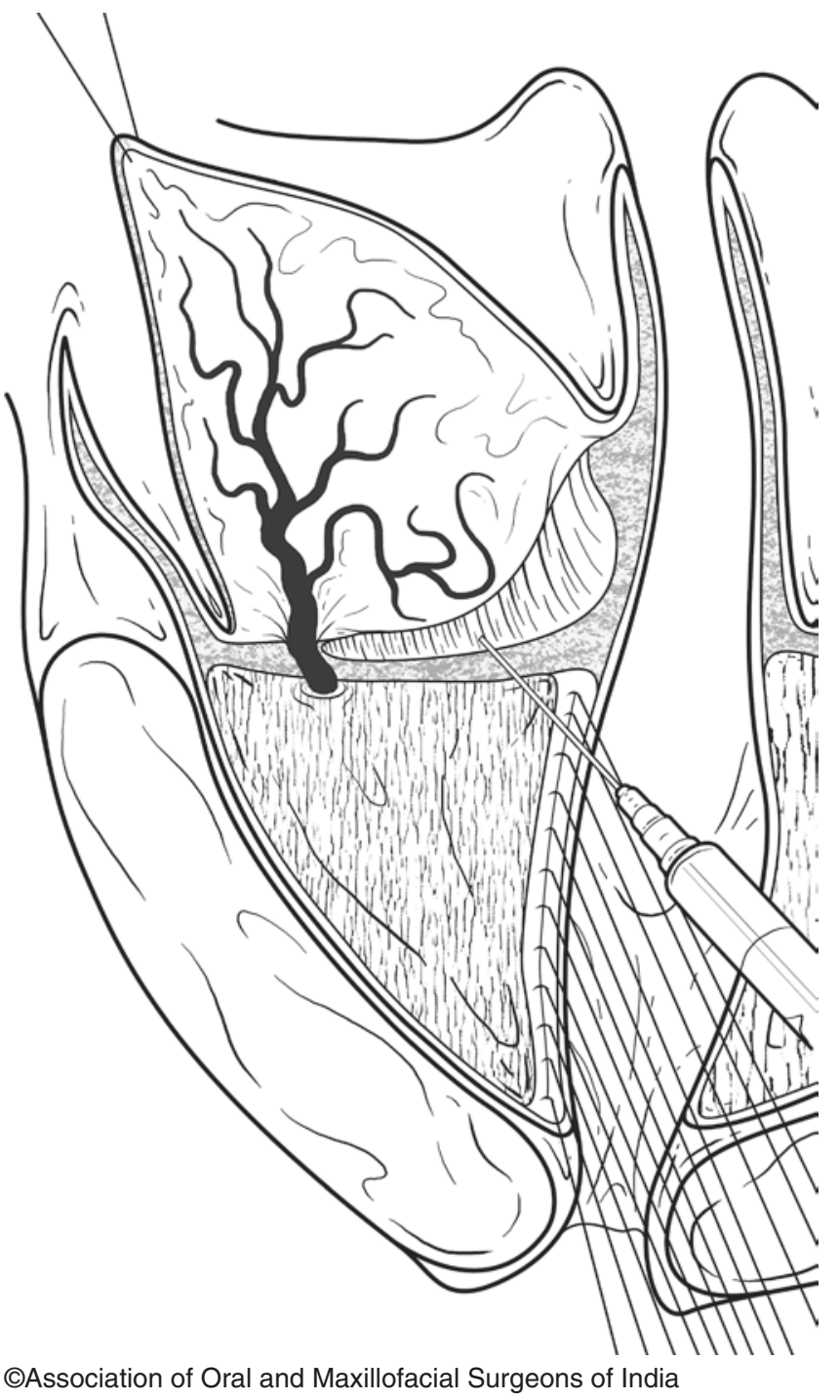

Fig. 73.23 Infiltration of adrenaline beneath the palatine aponeurosis 


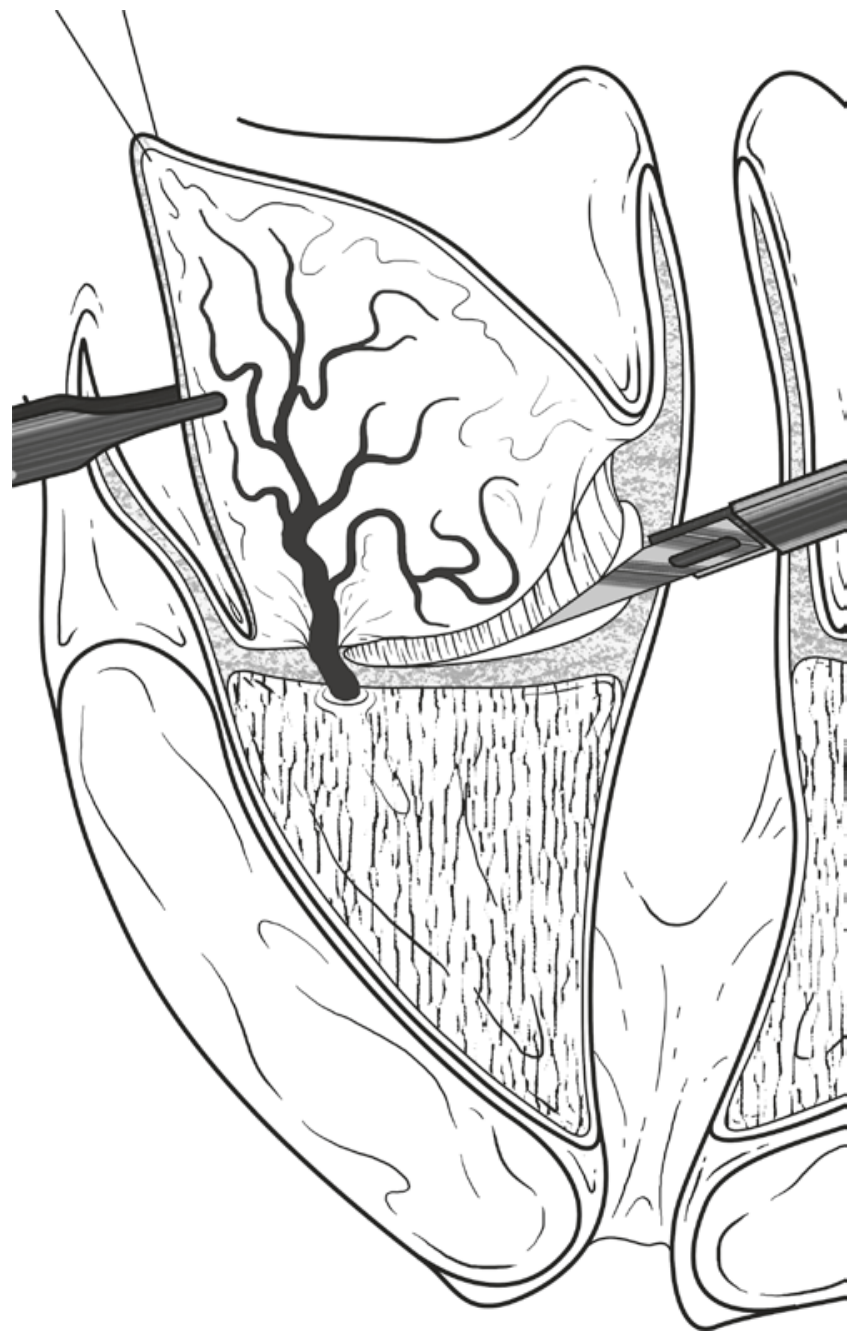

CAssociation of Oral and Maxillofacial Surgeons of India

Fig. 73.24 Incision of the palatine aponeurosis

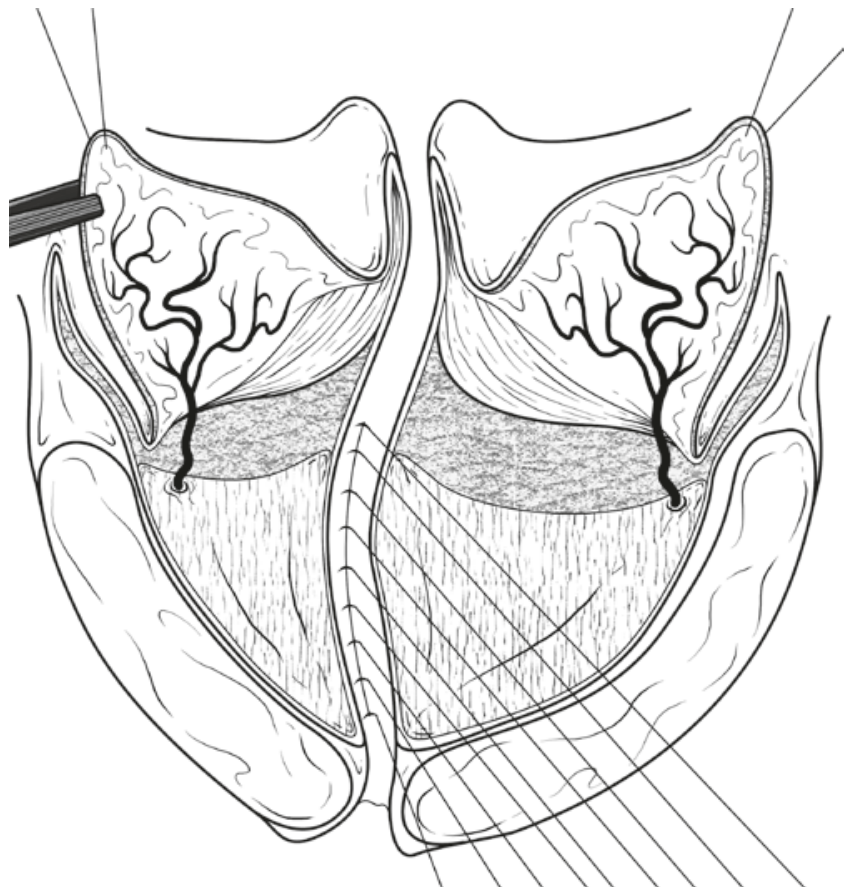

CAssociation of Oral and Maxillofacial Surgeons of India

Fig. 73.25 Complete dissection and retroposition of the levator palati muscle

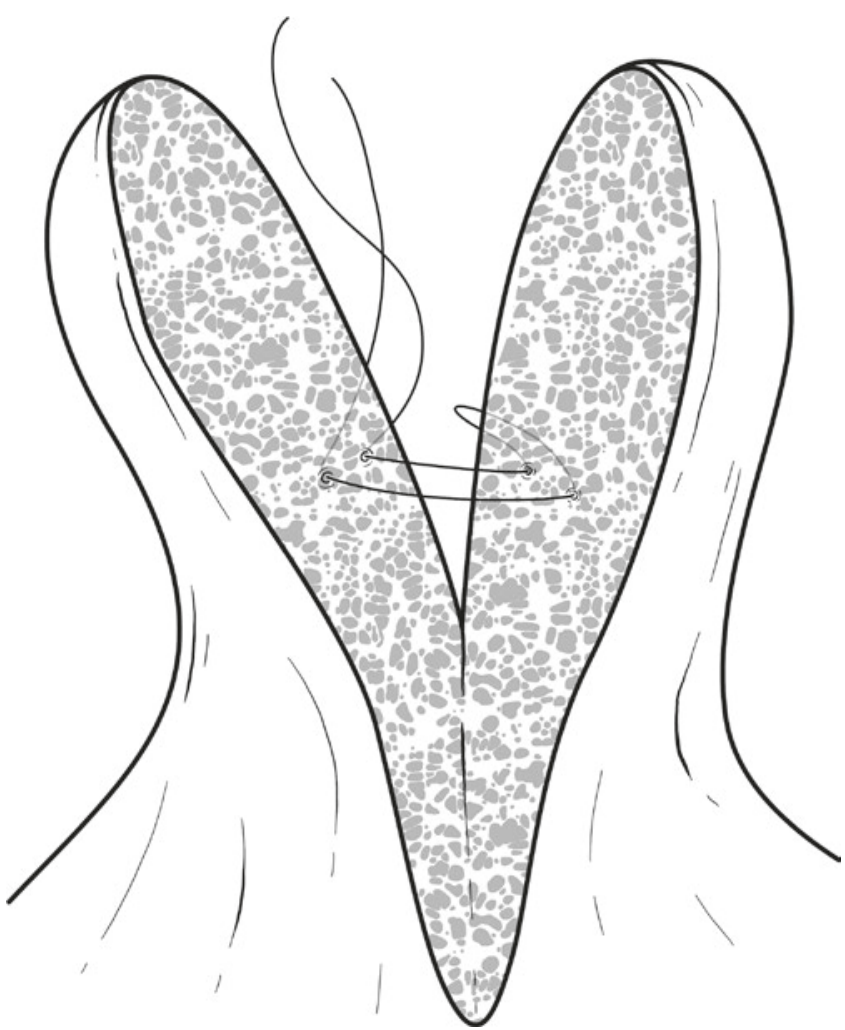

CAssociation of Oral and Maxillofacial Surgeons of India

Fig. 73.26 Mattress suture at the base of uvula 

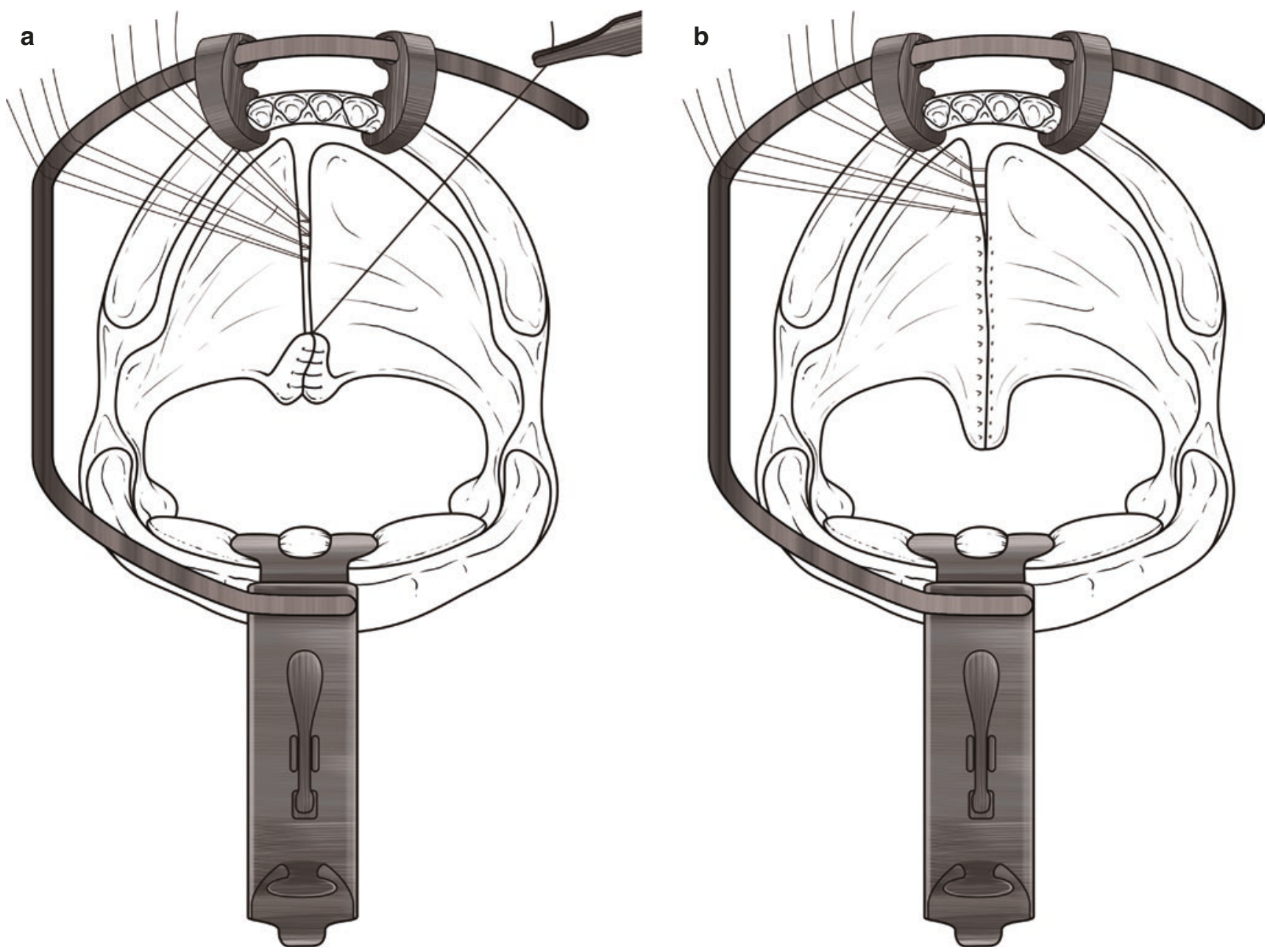

CAssociation of Oral and Maxillofacial Surgeons of India

Fig. 73.27 (a) Apical suture on uvula turned over and posterior sutures placed. (b) Completion of uvular reconstruction
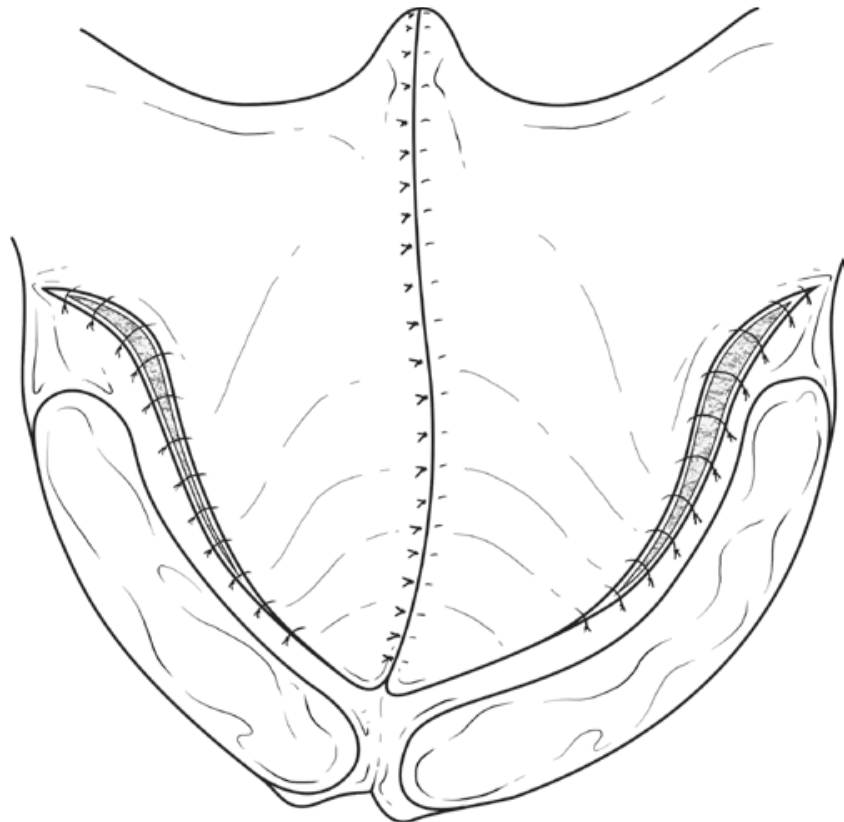

(C)Association of Oral and Maxillofacial Surgeons of India

Fig. 73.28 Completed suturing of the palate and the lateral raw areas

\subsubsection{Long-Term Complications}

Long-term complications include poor speech. Adequate muscle repair has helped in better speech results. Nonetheless, speech is an enigma that has not been adequately understood and mastered. The variables like width of the cleft, the gap between the uvula and the pharynx, and the adequacy of the muscle repair all have a bearing on the speech results. Despite all the advancements in the repair of the cleft palate, no surgeon can truly claim to achieve perfect speech results in all patients consistently.

\subsection{Long-Term Results}

The long-term evaluation of cleft palate patients should include the presence or absence of a fistula, the quality of speech, and the growth parameters of the maxilla, i.e., whether there is maxillary hypoplasia. 
At present, many centers are able to produce fistula-free palates in a majority of patients. Tension-free closure of the palate and meticulous suturing are the key factors in the prevention of fistulas. A review of literature reveals a huge range in the incidence of fistula after cleft palate repair. The range is from 2.6 to $58 \%$. In between these extremes, many have reported around $10 \%$, some 15 and $23 \%[31,32]$.

The emphasis on good levator veli palatini dissection and repair has led to improved speech results overall. However, one can never perfectly predict the speech outcome, as speech itself is an enigma. Probably as a result of the variation in the presentation, mode of repairs and age at the time of repair, etc., the published literature notes a VPI rate of $5.9-70 \%$ [32].

Maxillary growth continues to be a problem. Operations like these of Robert Mann show promise in this direction. Again, owing to variability involved in the type and extent of cleft, the time of repair and the nature of the surgery, the need for maxillary advancement may range from 10 to $40 \%$ in non-syndromic cleft patients [32].

\subsubsection{Secondary Repair and Revision}

The age old saying that primary surgery is the best chance for the surgeon to obtain optimal results is very apt in the repair of the cleft palate. A badly repaired cleft palate sometimes leaves behind a grossly scared palate with paucity of tissue. Small soft palate fistula can be repaired by freshening of the edge and two-layered closure. Small hard palate fistulas can be repaired by local turn over flaps for lining and oral mucoperiosteal flaps for the oral layer. Larger ones and those with poor speech will require revision palate repair. When there is gross deficiency of tissue, flaps like the tongue flaps, or temporalis musculocutaneous flap, facial artery muscle mucosal (Famm) flap may be necessary $[33,34]$.

Secondary palate repair is also required for velopharyngeal incompetence (VPI). A detailed discussion about the management of such incompetence is beyond the scope of this chapter. Diagnosis of VPI is by speech assessment, nasoendoscopy, or videofluoroscopy. Once a diagnosis is made, treatment modalities will include redo palate repair, sphincter pharyngoplasty, or flap pharyngoplasties, depending on whether it is the palate, lateral wall (palatopharyngeus) or the posterior wall, or a capacious pharynx as seen on investigations.

Subsequent interventions will be required for maxillary hypoplasia when significant. This is again out of the scope of this chapter. In brief, anterior maxillary distraction is done if the maxillary advancement required is significant and the facial bones are still growing. Some of these do require a LeFort 1 osteotomy later on if there is relapse.
When the growth is completed, then a LeFort 1 osteotomy is required when there is significant maxillary hypoplasia. When the advancement required is more than in $1 \mathrm{~cm}$, bijaw surgery is needed, with a LeFort 1 advancement in the maxilla and a bilateral sagittal split osteotomy of the mandible.

\subsection{Recent Techniques}

The use of the buccal mucosal flap in primary repair was pioneered by Padgett [14] and then used extensively by Murari Mukherjee [15]. Later Ian Jackson incorporated buccinator muscle into the flap and used it on the nasal layer transverse to provide for lengthening of the soft palate.

Furlow's Double Opposing Z plasty described by Furlow [35] is increasingly used both for primary and secondary repair of cleft palates. This illustrated in the figure (Fig. 73.29a, b, c and d). Robert Mann has described the extensive use of the double opposing " $Z$ " plasty with the buccal flaps over the nasal and/or oral layers to avoid lateral incisions and to promote for better bony growth. This is probably the method of the future as it shows promise of good speech and good maxillary growth. However, extensive suturing of the buccal flaps is involved and this is not the optimal surgery for the novice to try. The Mann procedure is for the experienced cleft surgeons [36].

\subsection{Case Scenario}

\section{Case 1}

This is a patient with a partial cleft of the secondary palate (Fig. 73.30). The hard palate is intact. The cleft palate was repaired at the age of 11 months using the Veau-Wardill V-to-Y repair and radical muscle dissection in the soft palate. Subsequently the child is undergoing regular follow-up and speech assessment.

\section{Case 2}

This is a child with a complete cleft of the primary and secondary palate on the (Fig. 73.31). The cleft lip was repaired at 6 months of age using the Millard's rotation advancement technique. At 11 months, the cleft palate was repaired using the two long-flap procedure popularized in India by Charles Pinto, the mentor of the senior author, and, worldwide, by Bardach. The child is now being subjected to constant follow-up and speech therapy. 

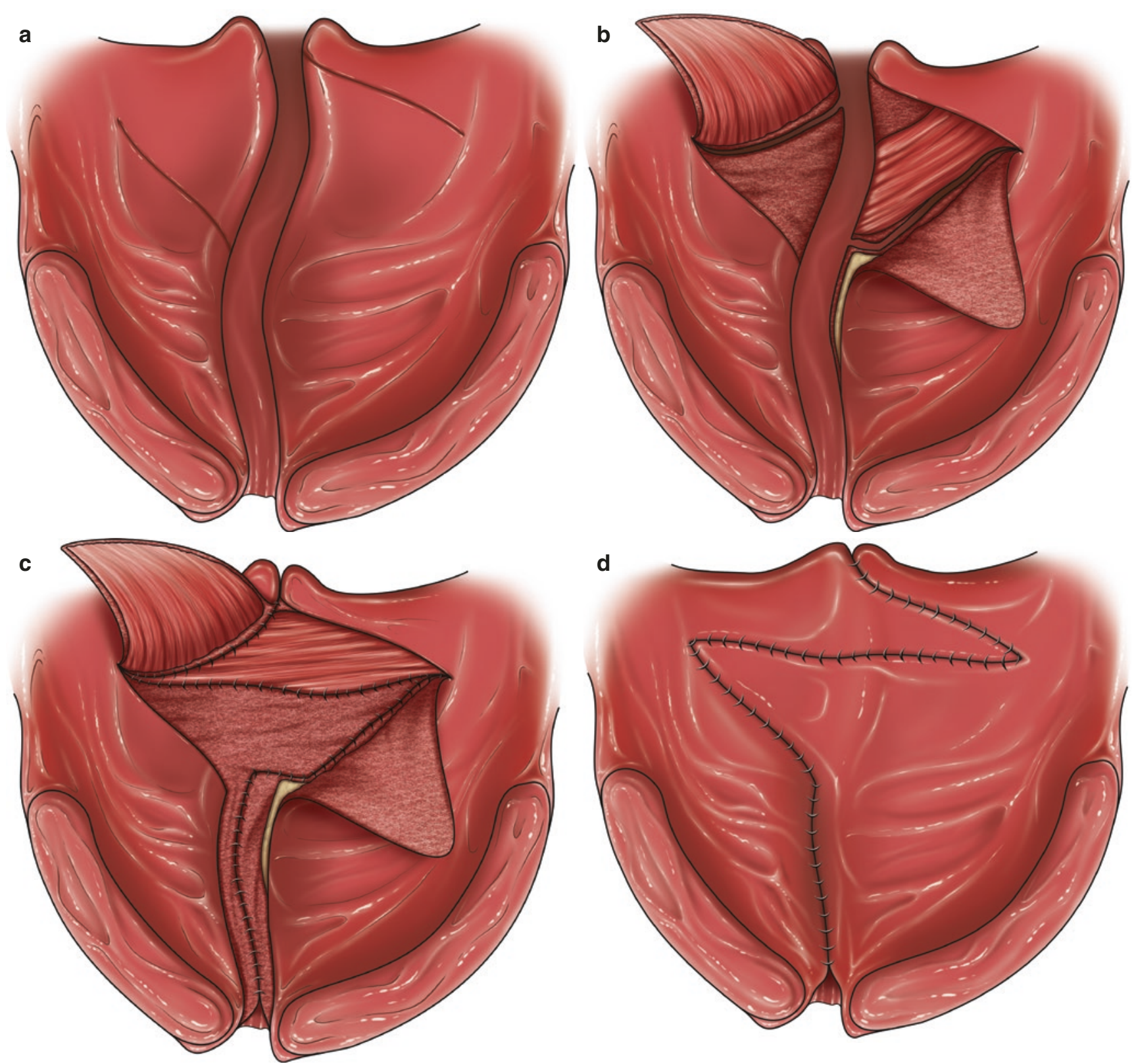

CAssociation of Oral and Maxillofacial Surgeons of India

Fig. 73.29 (a, b) Furlow's double opposing "Z" plasty (a) incision, (b) flaps raised and mucosal incisions placed, (c) double opposing Z plasty completed and (d) oral flaps inset 

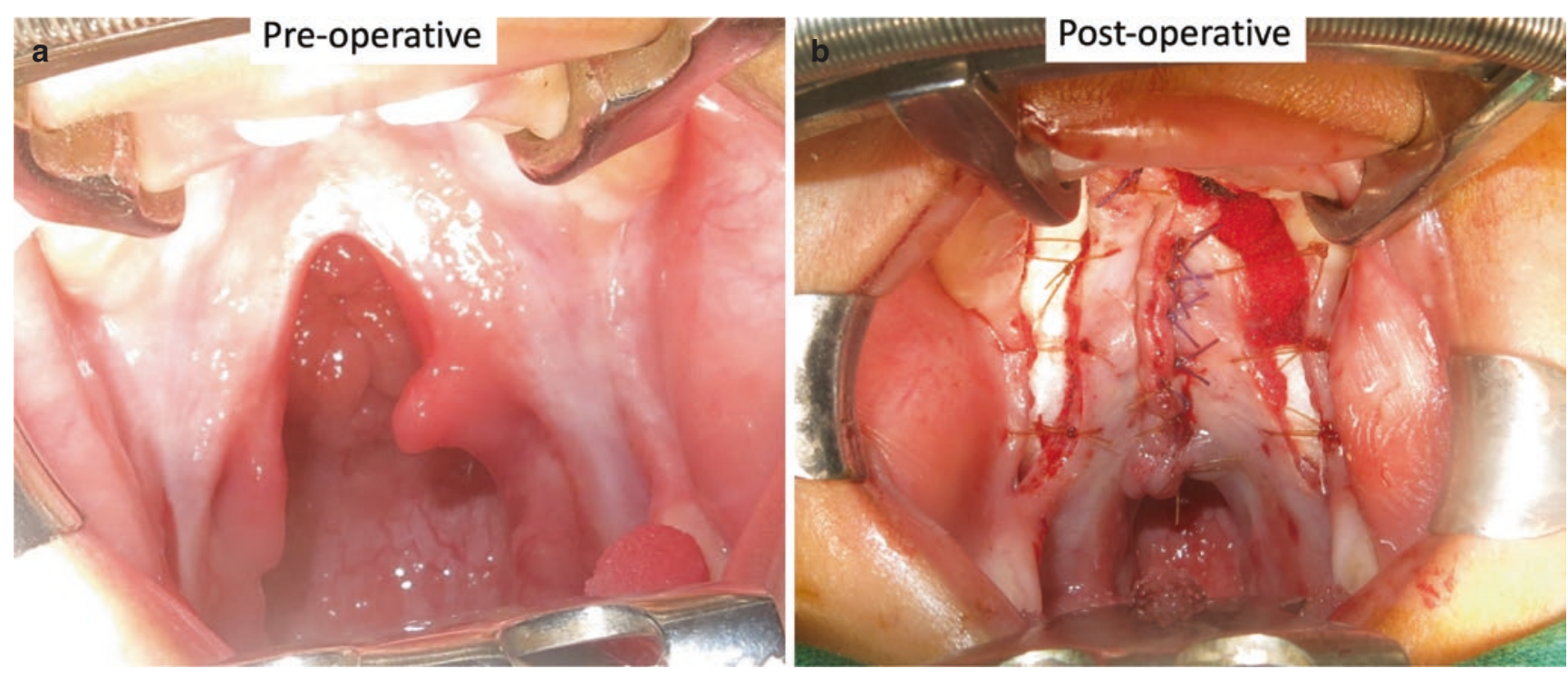

CAssociation of Oral and Maxillofacial Surgeons of India

Fig. 73.30 Repair of incomplete cleft palate
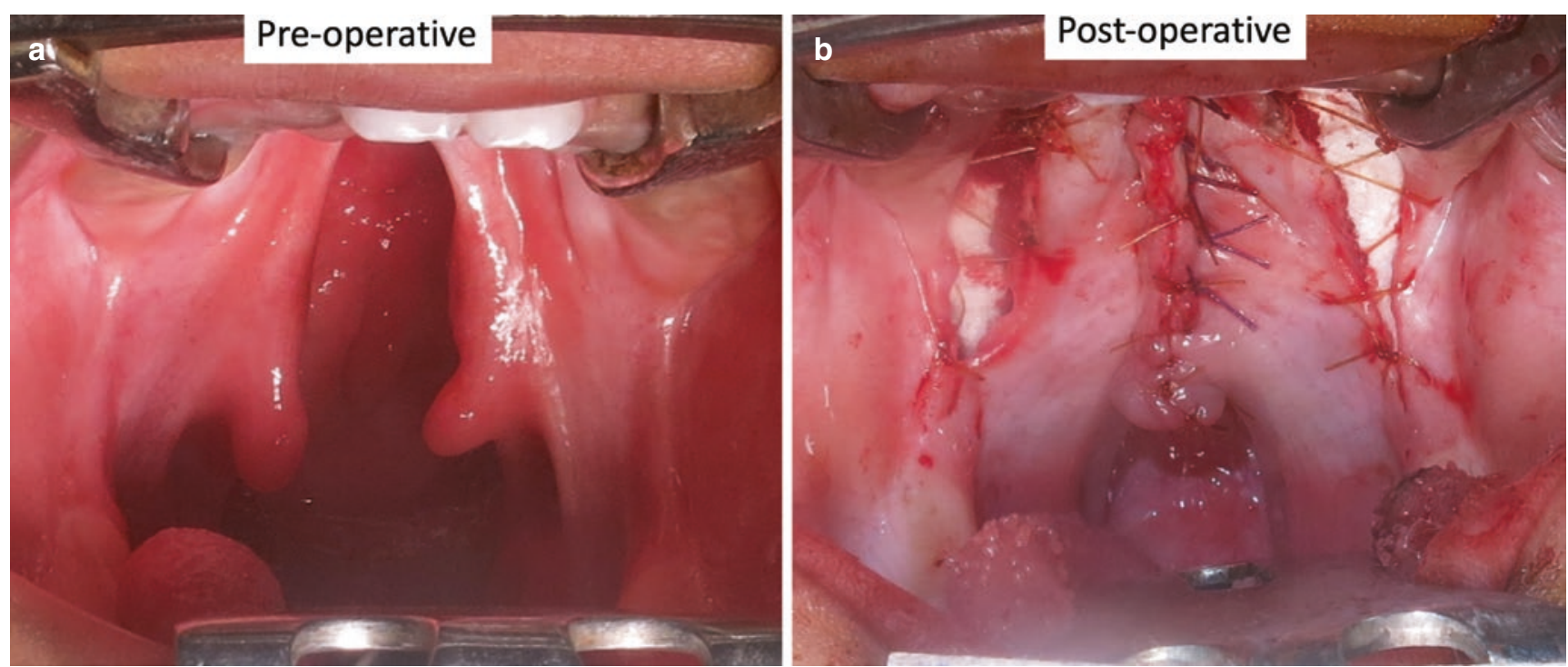

CAssociation of Oral and Maxillofacial Surgeons of India

Fig. 73.31 Repair of complete Cleft palate 


\subsection{Disclosure}

Authors have no financial conflicts to disclose.

\section{References}

1. Holdsworth WG. Cleft lip and plate, vol. 82. London: William Heinemann; 1957.

2. Von Graefe CF. Kurze nachrichten and auszuge. J Pract Azneck Wundarzk. 1817;44:116.

3. Randall P, Rossa D. Cleft palate in plastic surgery. In: JC MC, editor. Cleft lip, palate and craniofacial anomalies, vol. 4. Philadelphia: Saunders; 1990. p. 2723-4.

4. Dieffenbach JF. Die operative chirurgie, vol. 1. Leipzig: F.S. Brockhaus; 1845.

5. Warren JM. Operations for fissures of the soft and hard palate. Am J Med Sci. 1843;6:257.

6. Von Langenbeck B. Beitrage zur osteoiplastik. Deutsche Klin. $1859 ; 2: 471$

7. Veau V. Division palatine, anatomie, chirurgie, phonetique. Paris: Masson et cie; 1931.

8. Kilner TP. Cleft lip and palate repair technique. St Thomas Hosp Rep. 1937;2:127.

9. Wardill WEM. Techniques of operation for cleft palate. Br J Surg. 1937; $15: 117$.

10. Dorrance GM, Bransfield JW. The pushback operation for repair of cleft palate. Plast Reconstr Surg. 1946;1:145.

11. Cronin TD. Pushback palatorrhaphy with nasal mucosal flaps. In: Grabb WC, Rosenstein SW, Bzoch KR, editors. Cleft lip and palate: surgical, dental, and speech aspects. Boston: Little, Brown And Company; 1971.

12. Millard DR Cleft craft, vols. i, ii, iii. Boston: Little, Brown and Company; 1976, 1977, 1980.

13. Thatte R, Govilkar P, Patel J. The tongue flap in the primary treatment of cleft palate: a report of 19 cases. Br J Plast Surg. 1992;45(2):150-4.

14. Padgett EC. The repair of cleft palates after unsuccessful operations. Arch Surg. 1930;20:453-72.

15. Mukherji MM. Cheek flap for short palates. Cleft Palate J. 1969;6:415-20.

16. Mann RJ, Fisher DM. Bilateral buccal flaps with double opposing z-plasty for wider palatal clefts, Plast Reconstr Surg. 1997 Oct;100(5):1139-1143; discussion 1144-5.

17. Calnan J. Submucous cleft palate. $\mathrm{Br}$ J Plast Surg. 1954;6(4):264-82.

18. Sommerlad BC, Fenn C, Harland K, Sell D, Birch MJ, Dave R, Lees M, Barnett A. Submucous cleft palate: a grading system and review of 40 consecutive submucous cleft palate repairs. Cleft Palate Craniofac J. 2004 Mar;41(2):114-23.
19. Cohen MM. Syndromes with cleft lip and cleft palate. Cleft Palate J. 1978;15:306-28.

20. Randall P, La Rossa D, McWilliams BJ, Cohen M, Solot C, Jawad AF. Palatal length in cleft palate as a predictor of speech outcome. Plast Reconstr Surg. 2000;106:1254-9.

21. Åbyholm F. Primary closure of cleft lip and palate. In: Turvey TA, KWL V, Fonseca RJ, editors. Facial clefts and craniosynostosis. Philadelphia: WB Saunders; 1996. p. 370e383.

22. Friede H, Lilja J, Lohmander A. Long term, longitudinal follow up of individuals with UCLP after the Gothenburg primary early veloplasty and delayed hard palate closure protocol: maxillofacial growth outcome. Cleft Palate Craniofac J. 2012 Nov;49(6):649-56.

23. Agrawal K, Panda K ,A modified surgical schedule for primary management of cleft lip and palate in developing countries. Agrawal K, Panda K. Cleft Palate Craniofac. J. 2011;48(1):1-8.

24. Peet E. The Oxford technique of cleft palate repair. Plast Reconstr Surg Bull. 1961;28:282-94.

25. Lehman JA Jr, Douglas BK, Ho WC, Husami TW. One-stage closure of the entire primary palate. Plast Reconstr Surg. 1990;86:675-81.

26. Kane AA, Lo LJ, Yen BD, Chen YR, Noordhoff MS. The effect of hamulus fracture on the outcome of palatoplasty: a preliminary report of a prospective, alternating study. Cleft Palate Craniofac J. 2000 Sep;5:506-11.

27. Braithwaite F, Maurice DG. The importance of the levator palatini muscle in cleft palate closure. Br J Plast Surg. 1968;21:60-2.

28. Kriens OB. Anatomy of velopharyngeal area in cleft palate. Clin Plast Surg. 1975;2:261.

29. Sommerlad BC. A technique for cleft palate repair. Plast Reconstr Surg. 2003 Nov;112(6):1542-8.

30. Adenwalla HS, Narayanan PV. Primary cleft palate repair, surgical correction, facial deformity varghese mani. Kochi: Jaypee; 2010.

31. Lindsay WK, Witzel MA. Cleft palate repair: Von Langenbeck technique. In: Bardach J, Morris HL, editors. Multidisciplinary management of cleft lip and palate. Philadelphia: W.B. Saunders Company; 1990. p. 303.

32. Pomerantz JH, Hoffmann WM. In: Nelegan P, editor. Chapter 23 cleft palates in plastic surgery. 4th ed. Philadelphia: Elsevier; 2010. p. 579.

33. Gue-Santos J, Altamirano JT. The use of lingual flaps in repair of fistulas of the hard palate. Plast Reconstr Surg. 1966;38(2):123-8.

34. Pribaz J, Stephens W. Crespol, Gifford G. a new intraoral facial artery musculomucosal (Famm) flap. Plast Reconstr Surg. 1992;90(3):421-9.

35. Furlow LT Jr. Cleft palate repair by double opposing Z-plasty. Plast Recostr Surg. 1986;78:724-38.

36. Mann RJ, Martin MD, Eichhorn MG, Neaman KC, Sierzant CG, Polley JW, Girotto JA. The double opposing z-plasty plus or minus buccal flap approach for repair of cleft palate: a review of 505 consecutive cases. Plast Reconstr Surg. 2017 Mar;139(3):735e-44e.

Open Access This chapter is licensed under the terms of the Creative Commons Attribution 4.0 International License (http://creativecommons. org/licenses/by/4.0/), which permits use, sharing, adaptation, distribution and reproduction in any medium or format, as long as you give appropriate credit to the original author(s) and the source, provide a link to the Creative Commons license and indicate if changes were made.

The images or other third party material in this chapter are included in the chapter's Creative Commons license, unless indicated otherwise in a credit line to the material. If material is not included in the chapter's Creative Commons license and your intended use is not permitted by statutory regulation or exceeds the permitted use, you will need to obtain permission directly from the copyright holder. 